\title{
Intersectionality, Relativity and Multiple Deprivation in Upper Saponba Area, Benin City, Nigeria ${ }^{1}$
}

\author{
Chike F. Okolocha
}

\begin{abstract}
Intersectionality is discussed as a harvest of multiple disadvantages and deprivations by majority of urbanites. Parameters of disadvantage include cash poverty, poor health, lack of electricity, water and sanitation, proneness to crime and illiteracy, unemployment and underemployment. The study adopted a mixed method model and proceeded with a structured questionnaire administered to a sample of 1022 respondents in Upper Saponba area, the largest slum district in Benin City, southern Nigeria. Supplementary data were collected through in-depth interview with a purposive sample of 10 community members. Results seem to negate the culture of poverty hypothesis even as many poor residents express despair on the prospects of a good life in the city. This desolation coincides with new public policy by which governments withdraw from public space in the face of increasing poverty. We conclude that social intersectionality in urban Africa is a simultaneity of poverty and deprivations exacerbated by exclusionary public policies. Effectual public policy will depend on a recognition of the inter-linkages between parameters of disadvantage, deprivation and social exclusion.
\end{abstract}

Key words: intersectionality; nonindustrial country/society; over-urbanisation.

\section{Introduction: the research problem and literature review}

Toward the end of the $20^{\text {th }}$ century, urbanisation in the global south entered an overdrive, a trend which soon resulted in the overwhelming of the erstwhile world rural majority at the beginning of the $21^{\text {st }}$ century, precisely in 2007. Because the majority of humanity now lives in the city, the $21^{\text {st }}$ century was rightfully christened the urban century (Elmquist et al., 2019; OECD, 2015; Kourtit et al., 2015; Kourtit and Nijkamp, 2015; Brenner and Schmid, 2014; Satterthwaite, 2007). This broad sweep of trends oversimplifies global urbanisation, for there was a great variety in the trends in various parts of the world (Farrell, 2017). Beginning from about 1850 when a country (England) first attained an urban status, there has been no looking back (Steinsson, 2020; Mohajan, 2019; Ashworth, 2017; Horn et al., 2010). Other European countries joined the train of the Industrial Revolution, and quickly became urban without exception, thus confirming the hypothesis that industrialisation is perhaps inseparable from urbanisation (Rabb and Rotberg, 2014; Harley, 2013; Mathis, 2013; Hofmann and Wan, 2013; Cameron, 1983). Across the Atlantic, the United States literarily belled the cat by becoming an urbanised country in 1920 following its own Industrial Revolution (Bouston et al., 2013).

'Auth or is grateful to Dr James Okweshine of the Department of Economics, University of Benin for his comments on this paper. 
Intersectionality, Relativity and Multiple Deprivation in Upper Saponba Area, Benin City, Nigeria 90

Although the countries of the dominated parts of the world lagged behind, they nevertheless joined the global trend towards urban living, albeit without industrialisation. In fact, Latin America now has the largest proportion of urban dwellers in the world, growing from 40 per cent in 1950 to 70 per cent in 1990 and over 80 per cent today, thus surpassing the entire European Union which became urbanised earlier on (Portes and Martinez, 2019; Arsht, 2012; Rodgers et al. 2011). Noteworthy is the fact that Latin America's speed of urbanisation was not fuelled by a Europeantype Industrial Revolution. Granted that pre-World War II false-steps in industrialisation actually precipitated rapid industrialisation in the region, there was no collateral growth in wealth. Recent strides in industry and technology have not dimmed the poor-fare of Latin American urbanites (Alvarado and Muggah, 2018; Ioris, 2015).

Another trend of urbanisation is represented by the experience of Africa where imperial-colonial relationships with Europe gave rise to the modern city, which lagged behind its European counterparts because of the near-total absence of industrialisation (Castells-Quintana and Wenban-Smith, 2020; Avis, 2019; Farrell, 2018; Okeke, 2017; Muhhamed et al., 2017; Dodman et al., 2017; Bloch et al., 2015; Jedwab et al., 2013; Hove et al., 2013). Thus, modern urbanisation in Africa has been a function of the growth of modern cities without a modern industrial economic base. Rapid urbanisation after independence was a response to promises of freedom and the optimistic growth ambitions of nationalist leadership. The failure of these promises and ambitions did not deter urbanisation under the spectre of rural decay, disorganization and immiserisation (Babatunde and Oyejide, 2017).

The global urban built-up area is already 73 million ha and this is projected to grow by a further 153 million ha by 2030 (Florczyk et al., 2020; Li et al., 2019; He et al., 2019; Angel et al., 2005). As current trends indicate, this expansion is almost entirely restricted to poor (or developing) countries where 93 per cent of global urbanisation is now taking place (because the urban transition has already been completed in the rich, industrial or developed countries) (Fox, 2011; Cohen, 2006).

Globally, physical expansion seems to be matched by economic growth as just 600 urban centres generate about 60 per cent of the world's GDP (Ritchie and Roser, 2019; Colenbrander, 2016; UN-Habitat, 2011; Dobbs et al., 2011). However, if the established trend of rapid urbanisation without concomitant industrialisation in poor countries continues, urban life in these countries will boil over into a melodramatic spectacle as Lagos grows from a megacity of 20 million today to the world's leading megalopolitan monster of 89 to 100 million in 2100 while Niamey in Niger Republic, the country with the world's highest birth rate, will grow from a mere 1.3 million in 2020 to an unimaginable 46 million in 2100 (Vidal, 2018; Avakian, 2018; Hoornweg and Pope, 2016). Such growth trends throw up sustainability challenges which negate the historical Brightside of urbanisation. As poverty is increasing in tandem with urbanisation, over 60 per cent of African population is already living in slums, the principal slum region in the world (Onapajo and Uzodike, 2017; Raleigh, 2015; Beall and Fox, 2012; Mabogunje, 2005). 
Rapid urbanisation in poor countries arising from the gross mismatch between population and resources has led to widespread scarcities and an internecine dogfight among urbanites for advantage. Among the graver manifestations of this scenario are crime, violence and insecurity, unemployment, social exclusion, poverty and inequality, overcrowding, poor sanitation and health challenges, housing shortages, environmental degradation and slums (Muhammed et al., 2017; Tacoli et al., 2014; Patel and Burkle, 2012; Khan, 2008). These problems are exacerbated by weak governance and frail institutions. Of course, challenges of rapid urbanisation in poor countries constitute a paradox considering the potentials of the city as the engine room of economic growth and development (Turok and McGranahan, 2019; Muggah, 2013). Scholars have recognized the paradox of this double-edged character of urbanisation, yet they have only just started paying attention to the intersection and mutuality between the negative fallouts of urbanisation (Scheim and Bauer, 2019; Noll, 2019; Roberts et al., 2019; Broto and Alves, 2018; Earnshaw et al., 2018; Walby et al., 2012).

In the rest of this paper, we present recent empirical data to exemplify the multiple intersection of urban marginalities. Intersectionality assumes that the lived experiences of people are affected by their age, ethnic, class, gender, geographic, religious and other identities which affect each other and continually operate in concert to determine social reality (Larson et al., 2016). In this study, we examine how the various malevolent fallouts of rapid urbanisation collectively affect slum dwellers.

\section{Objectives of study}

The study aims to examine how intersectionality theory may be deployed in explaining multiple deprivation in the life of slum dwellers in Upper Saponba area (USa), Benin City. More specifically, we aim to investigate how various manifestations of deprivation and social exclusion interact and interconnect. This will be achieved through a focus on the following:

a. An examination of the nature and extent of despondency among slum dwellers in USa and the hypothesis of the culture of poverty. Here we seek to explore a seeming failure of slumdwellers to take advantage of opportunities to breakout from poverty,

b. An exploration of the interlink ages between slum dwelling and health behaviour in USa. Our purpose here is to interrogate the plausible fatality in the health behaviour of poor people.

c. (c) Analysis of slum dwelling in USa and the crisis of infrastructure deficits. This objective seeks to explore probable inherency between slum dwelling and infrastructure deficits.

d. (d) An evaluation of the incubus of insecurity in the life of slumdwellers in USa. Is insecurity an independent variable in the intersectionality of our parameters of deprivation and social exclusion in the area? 
Intersectionality, Relativity and Multiple Deprivation in Upper Saponba Area, Benin City, Nigeria 92

\section{Theoretical framework}

In this study, the distinction between structural and political intersectionality is underplayed because the former is sustained or underpinned by institutionalised political power. Therefore, the inequalities and marginalities under reference are at once structural and political (Walby et al., 2012). Slums are structurally marginal sections of the city which are sustained by the power advantage enjoyed by the dominant elite. In spite of this urban class cleavage and the apparent intraclass disparities inherent in USa, we present the slum as a recognizable but heterogenous social category. The intersecting marginalities in the slum are not conceptualised by the victims as a function of social relations with dominant groups, rather slum dwellers see themselves as belonging together in a marginal area without any consciousness of intra-category distinctions or animosity against the absentee dominant groups. Because of the nonappearance of any overt consciousness or ingroup/outgroup hostility, social distinctions in the slum may best be described by the concept of horizontal inequality (Stewart, 2017; 2015) which may approximate to the Marxian class in itself.

However, our analysis of the intersection of urban marginalities tends to ignore the actions of a powerful outgroup, whereas the social category of the slum will not exist without the latent complicity of the dominant groups. In other words, the slum is not just a creation of slum dwellers but a function of the contradictions of economic liberalism and the convenience of the dominant groups who possess the power and resources to prevent or ameliorate it. We also did not create an "oppression Olympics" by classifying some deprivations as more depressing or important than others (Hancock, 2007). Instead, we merely present the deprivations as social facts working together to the disadvantage of slumdwellers. For heuristic purposes, any parameter of disadvantage may be conceptualised as the key variable, a position which may easily be validated with empiric data.

\section{Conceptual framework}

The framework depicted in Figure 1 conceptualises slum dwelling as an intersection of disadvantages and deprivations where any of the parameters could be an independent variable. For example, taking slum dwelling as an independent variable, it is obviously a constellation of malevolent consequences of poverty, unemployment, insecurity, poor health and decadent infrastructure. In other words, without the slum, the various parameters may not manifest or may do so partially. Similarly, unemployment may be an independent variable if we consider that it may be responsible for poverty, ill-health, etc. Put differently, we can say, for example, that the slum is a function of unemployment which, in turn, is also a determinant of poverty, poor health and poor infrastructure. Consider also that poverty may lead to insecurity. In short, slum dwelling is a vicious cycle of intersectionality of parameters of disadvantage. 
Figure 1. Conceptual framework

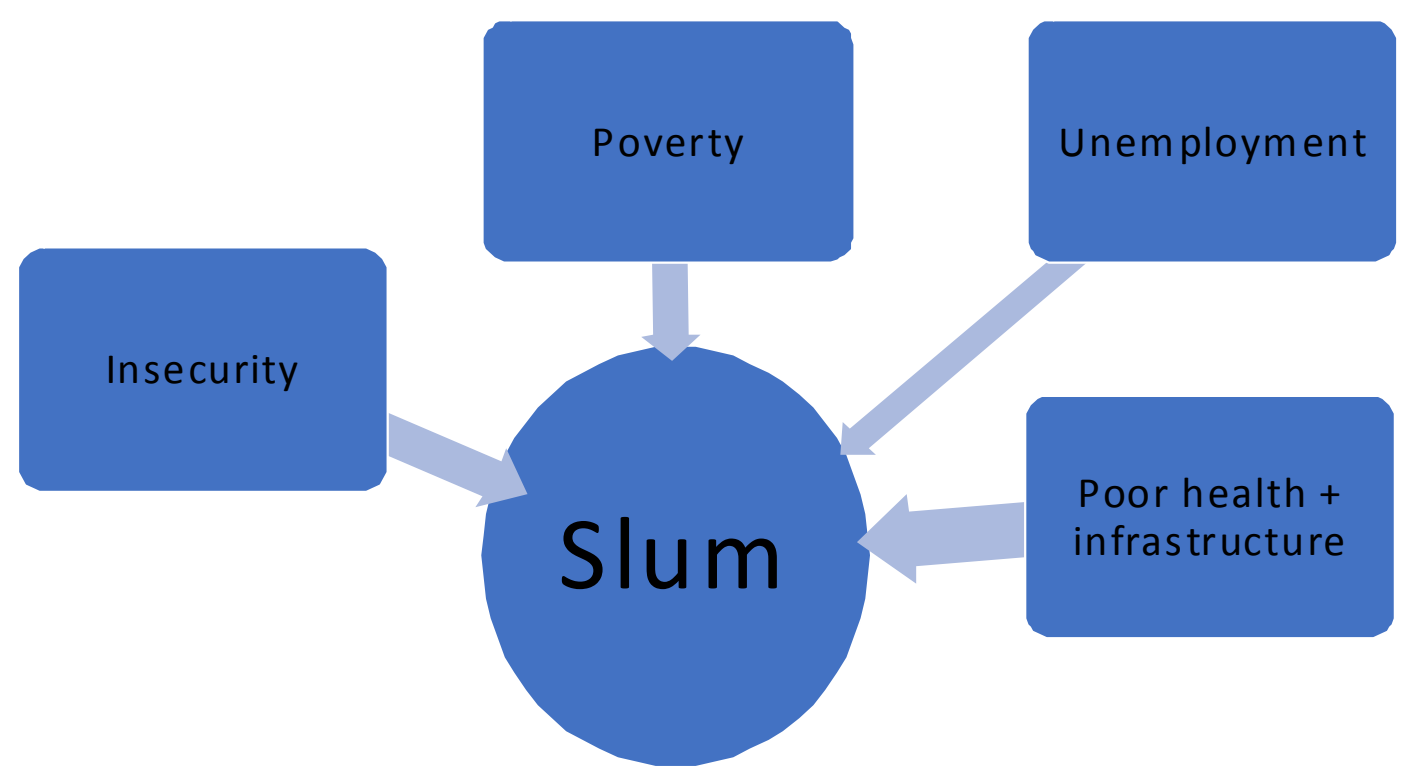

Intersectionality does not only mirror inequality in infrastructure and services in the city but it is also key in reproducing spatial as well as socio-political exclusion. Our basic assumption is that slum dwelling is an intersectional synthesis of the mutually reinforcing negativities of parameters of disadvantage and deprivation in USa.

\section{Method}

The study adopted the mixed method model, involving a combination of related methods at various stages. Mixed method research is a pragmatic paradigm which combines the strengths of both positivism and interpretivism, thus affording the researcher the eclecticism to achieve objectives in actions research (Igun, 2015). Being a case study, adopting the mixed method model was a conscious effort to enhance its scientific status and validity.

\section{The study area}

Study was carried out in USa, the largest and most visible slum district in Benin City, the rapidly growing capital of Edo State, southern Nigeria. USa is a fast-growing, poor, densely populated and dangerous straggly slum area notorious for crime and lack of basic municipal services and utilities. Situated to the south-east of the city, the slum has merged imperceptibly with the neighbouring settlement of Idogbo, headquarter of the Ikpoba-Okha Local Government Area (LGA). Like all slums, USa is physically degenerate and unplanned, but it is defined by a major thoroughfare, Upper Saponba Road, which bifurcates it into two distinct and somewhat equal sections. Because of the elevation of this road, streets lying to either side of it are liable to annual floods as there is no effective drainage channel. Of the 154 side streets that join this arterial road on either side, only 22 
Intersectionality, Relativity and Multiple Deprivation in Upper Saponba Area, Benin City, Nigeria 94

are paved but in various states of disrepair. Upper Saponba Road is itself ill-maintained and some sections are under water during the rainy season. Because of the intense commercial activities on either side of the road, there is heavy human traffic, a situation worsened by a most chaotic vehicular traffic. To all intents and purposes, USa is visibly excluded from the scheme of things and there appears to be no political will to ameliorate its physical and environmental dissoluteness.

\section{Study population}

The population of USa is unknown and therefore a matter of great conjecture. The parent settlement, Benin City, had an estimated population of 1,727,169 in 2020, with roughly 345,434 households if we assume an average household size of 5. However, it is not certain which proportion of this population is domiciled in each of the four LGAs in the city: Egor, Ikpoba-Okha, Oredo and Ovia North East. Of these, Oredo is entirely within the putative city limits but its extent in the other three LGAs is ambiguous. Based on projections from the 2006 population census by the Nigeria Population Commission, USa as a major population centre in both Oredo and Ikpoba-Okha LGAs, may already be in excess of 500,000, giving a total of no less than 100,000 households in the area.

\section{Sample and Sampling}

Through the single-case study and the use of multiple sources of evidence, the quagmire of rigorous sampling was side-lined. A standardized questionnaire was administered to sample was 1022, drawn through accidental selection of cases in all 154 streets in USa, thus reducing the risk of sampling bias. These streets constituted our sampling frame. In addition to reducing the risks of unrepresentativeness and inadequacy of nonprobability, the purpose of such a large sample in a single case was to achieve a repetition logic in place of a sample logic in scientific surveys. With a large sample, our explanatory case study stands in a better stead of yielding a more holistic knowledge and giving a clearer picture of our research objectives (Teegavarapu and Summers, 2008). Questions were guided by falsification logic such that respondents could freely negate research presumptions, as against the analytic logic that is said to foster generalisations. Moreover, supplementary data were collected through in-depth interview with a purposive sample of 10 community members. This is in addition to the technique of non-participant (direct) observation by which the researcher was able to directly observe some of the variables in the study.

The conceptual universe of the study is Benin City but data were collected from USa which therefore served as the empiric universe. As a case study, findings may not be generalised (an allegation denied in Flyvbjerg, 2006) or be representative of the reality in other slums in the city, yet they readily present a template for comparative analysis. Questions in the first section of the questionnaire elicited information on the basic demographic data of the respondents who were chosen because of their headship of their households. The other sections of the questionnaire were dedicated to the substantive issues of the research, including the controversy of the culture of poverty, proneness to crime and other indices of social exclusion and deprivation. 
95 Annals of the Social Academy, Nos. 22, Jan.-Dec., 2018/2019

\section{Data analysis}

The qualitative data from the interviews were analysed thematically using direct comments from respondents. On the other hand, the quantitative data were presented in frequency and contingency tables along with descriptive inferential statistical tests. To further understand the objective of this study the Chi-square test for independence is adopted. The test is used in situations where a population is structured in two different categories. Each category is divided into two aspects. This is to find out if these two categories are independent, that is, there is no relationship between the categories at a particular significance level (d".05) which may be captured using a probability value (p. value) (Albright et al., 2009).

\section{Findings \\ Basic demographic data}

A little over 60.0 per cent of the respondents was male, 53.0 per cent was constituted by those 36 years old or older while 58.0 per cent was made up of married persons, indicating a mature adult sample.

With respect to educational attainment, there was no respondent without some education as Edo State belongs among the educationally advantaged states in Nigeria. There are four universities in Benin City and dozens of primary and high schools. A total of 67.0 per cent had low educational qualification, of which less than 3 per cent had only primary school education. Because the sample was made up entirely by mature people, a total of 66.0 per cent constituted of working persons. Among respondents not working were students and apprentices ( 4.4 per cent) and the unemployed (8.6 per cent). The low percentage of persons not working is probably due to our focus on household heads while the low percentage of the unemployed belie the much-orchestrated high unemployment rate in Nigeria. Perhaps high unemployment rates exist only among the youth.

However, it is noteworthy that 49.9 per cent was constituted by informal economy operators such as traders, artisans or farmers. Another significant group making up 33 per cent of the sample was constituted by respondents employed in the formal sector (teachers and civil servants). In other words, the largest proportion of the respondents was made up of the self-employed who are entirely in the informal sector. With respect to income, a majority of the respondents (56.1 per cent) claimed a low income, here defined as the national minimum wage of 30 thousand naira (US\$75.90) or less every month. This is made up of those who indicated they earned no income (students, apprentices) as well as artisans and traders.

Low-income earners are largely operatives in the informal sector, a looming sector, perhapsthe largest in the Nigerian economy. Among the high-income earners (that is, anything above the national minimum wage) in the sample are senior civil servants and businesspersons. In view of the low 
Intersectionality, Relativity and Multiple Deprivation in Upper Saponba Area, Benin City, Nigeria 96

income claimed by our respondents, it is not surprising that a majority of them ( 59.4 per cent) is made up of tenants while 22.7 per cent owns their dwelling units as landlords. The rest is made up respondents who do not own their houses, yet do not pay any rent as their houses are owned by their parent or other relative. Finally, because USa is situated in a predominantly Christian city, 88.3 per cent of the respondents professed Christianity, mainly of the numerous protestant denominations.

The culture of poverty refers to a scenario in which poor people tend to accept their stations in life and develop attitudes which rationalise and justify their being poor. Poverty itself is a persistent social problem haunting humanity (Ferreira et al., 2015; Walker et al., 2013). Its most basic manifestation is the lack of material resources loke food, clothing and shelter. Basically, culture of poverty is operationalised as resulting from local cultural norms and standards of behaviour (Scroggins, 2015; Harkness et al., 2013; Rogalsky, 2009). What people learn or grow up with tend to shape their life and constrict the choices they make. Therefore, poverty emanates from accepted and normal social life.

If culture of poverty reflects normative behaviour, then it amounts to despondency on the part of the poor. The hypothesis amounts to wilful failure or inability to take advantage, or the institutionalisation of hopelessness. In this section, I examine how the propensity to take loans may be influenced by income, occupation, housing type and gender.

Recent public policy has conceptualised small loans (microcredit or microfinance) for artisans and traders as incentives to facilitate their breakout from poverty. Officials often present small loans for small (or poor) people as a veritable deux ex machina against poverty, yet results do not seem so promising or straightforward (Mecha, 2017; Abdullahi et al. 2016; Fafchamps, 2013; Sandven and Thormodsen, 2012; Acha, 2012; Duvendack, 2011; Khawari, 2004). Acceptance or failure to accept such incentive may define the strength or fallacy of the culture of poverty hypothesis.

\section{Occupations and propensity to taking loans}

Traders/businesspersons, farmers, artisans and the unemployed are grouped into the informal sector while students/apprentices, teachers, civil servants and the retired are included in the formal sector. In the informal sector, trading/businesspersons constitute the largest category of respondents who had benefitted from formal microcredit with artisans as the next largest group of respondents that took loans.As shown in the Table 2, a majority of 86.7 per cent of the respondents had not benefitted from formal microcredit and had never taken any loans. Of the 13.3 per cent that had ever taken a loan, 2.8 per cent are informal sector operatives. Among them a majority of 80.0 per cent had never taken a loan while among those in the formal sector, 92.7 per cent had never taken a loan. 
Table 2. Occupation And Propensity to Loan Taking

\begin{tabular}{|c|c|c|c|c|c|c|}
\hline Loan & $\begin{array}{l}\text { Occ } \\
\text { For } \\
\mathrm{N}\end{array}$ & & $\begin{array}{l}\text { Info } \\
\mathrm{N}\end{array}$ & $\%$ & $\begin{array}{l}\text { Total } \\
\mathrm{N}\end{array}$ & $\%$ \\
\hline $\begin{array}{l}\text { Yes } \\
\text { No } \\
\text { Total }\end{array}$ & $\begin{array}{l}11 \\
385 \\
396\end{array}$ & $\begin{array}{l}2.8 \\
97.2 \\
100.0\end{array}$ & $\begin{array}{l}125 \\
501 \\
626\end{array}$ & $\begin{array}{l}20.0 \\
80.0 \\
100.0\end{array}$ & $\begin{array}{l}136 \\
886 \\
1022\end{array}$ & $\begin{array}{l}13.3 \\
86.7 \\
100.0\end{array}$ \\
\hline
\end{tabular}

Pearson chi-square $=62.1 ; \mathrm{p}$. value $=0.05 ; \mathrm{df}=1$; with $\mathrm{p}$. value $\hat{A}$.05level, we assume a significant relationship between the variables.

The Pearson chi-square result of 62.1(p-value, 0.000$)$ shows that there is a significant relation between the taking of loan and occupation in USa. This explains that those in the informal sector are actually in need of micro-credits even when many of them from the study have not collected any microcredit loans.

Generally, it would seem that the occupation of respondents has some noticeable influenceon their predisposition to microcredit. Now the critical question: why is the population of USaaverse to formal microcredit? Negative attitude toward microcredit is a grave matter that contradicts poverty and fuels the theory of culture of poverty which assumes that poor people fail to avail themselves of microcredit even when the conditions are said to be very genial or with minimal interest rates. However, the negative disposition of poor people to microcredit may be a function of factors outside the culture of poverty. For example, an early warning from Marr (2004) points to the fact that negative perception of microcredit may be attributable to a communication gap between poor people and formal fund providers. Further, empirical study by Cwynar et al. (2016) confirmed that negative perception of microcredit by recipients derives from the adverse experience of beneficiaries, not a culture of poverty or despondency. Emerson (2010) has also presented data to show that microloans may be bad for growth.

In traditional society, debtors are unhappy people while loan sharks are feared and detested. Even so, in modern society, banks do not appear to understand the needs of the poor or how they manage their finances (Banerjee and Duflo, 2011). Therefore, aversion to microcredit may be synonymous with aversion to risks associated with indebtedness to individuals, government, banks or loan sharks, not a manifestation of despondency or culturally ingrained unreadiness to take advantages. Shunning microcredit is thus an escape valve because poor people conceptualise it as a trap, even as they concentrate in accumulating capital through daily contributions or rotational credit clubs (Esusu). On the popular TraderMoni and Marketmoni, two federal government microfinance schemes for small-scale businesspersons and traders, a woman trader said:

TraderMoni is not for everybody and I don't think there is no interest charge. You have to pay to register. If government wants to help us, it should give us money. During elections, they bring free money but now they want us to take loans. I will not apply because I don't want to be a debtor. I am already a poor woman and a loan will add to my poverty (Interview with trader [F] aged 44, 10/09/19). 
Intersectionality, Relativity and Multiple Deprivation in Upper Saponba Area, Benin City, Nigeria 98

Yet considering that 80.0 per cent of informal sector operatives had not taken loans at the time of the study, it is obvious that loan-taking is an exceptional behaviour among them. On theother hand, respondents in the formal sector who had taken loans are fewer even though it is speculated that people with steady incomes like teachers and civil servants should be more positively disposed to loans. We must therefore return to our argument that poor people are averse to risk-taking hence the negative disposition to loans. Apathy toward loans is exemplified by the response of a tailor who had three apprentices and a journeyman in his shop. According to him:

\begin{abstract}
If I take a loan, my business might fold up as I cannot be sure I can make enough profit to repay. To take a loan is easy but repayment is the trouble. I have built up my business without a loan and I am able to pay my rent and the school fees of my children. Sometimes business is not good, so if you take a loan and things go bad, you will be in trouble. If you take a loan from a bank, they will end up taking your business from you (Interview with a tailor [M] aged 35, 04/10/19).
\end{abstract}

For the reason of this seeming apathy and aversion toward loans, we may hypothesize that informal sector operatives are less likely to take loans and therefore are more likely to remain small scale entrepreneurs indefinitely. Opportunities provided by government for such persons to secure soft loans may not be utilized.

\title{
Gender, housing type, and propensity to take loan
}

Table 3 presents the probable interaction between different types of house occupancy, gender and the propensities to take microfinance loan among the respondents. Notice that the category of tenants forms a majority of the respondents and are arguably among the poorer members of our research population. A vast majority of their members (91.9 per cent) had not taken any loan previously. Even among the houseowners and free-stay occupiers who are spared the financial burden of paying house rents, there is also a notable apathy toward loans as 79.0 per cent had not taken any loan in the past. Although these are persons who enjoy the financial freedom of rent-free accommodation, it is uncertain if they are classifiable as well-off. Were that to be the case, chances are that they would seek better accommodation elsewhere. Some of them may be passed off as freeloaders staying in family houses because they cannot afford to pay rent or build their own houses while others who may be well-off and can afford rented accommodation are obligated or prefer to stay in family houses. While staying in free accommodation may not necessarily indicate poverty, it may perpetuate dependency and poverty of such persons. This scenario can hardly be classifiable under the culture of poverty because free accommodation may only be circumstantial, not a function of poverty or despondency.

On gender, the key question is whether men are more averse to microcredit than women. A look at the data will lead to such a deduction as a greater proportion of men (87.6 per cent) compared to 85.3 per cent for women had not taken any loans. Considering that there are more men than women in the sample, we are encouraged to underscore such conclusion. However, this does not 
diminish the fact that only a very small percentage (12.4 per cent of men and 14.7 per cent of women) had ever benefitted from microcredit. Probably because of the ready credit available from daily contributions and esusu, this study did not discover any enthusiasm for taking loans from formal sources (that is, government and banks) to improve petty trading. According to a notable local woman market leader in our research area:

I don't require a loan for my trade. I do daily contribution and I belong to two esusu groups.
I have grown my business with money from these sources. If I take a loan and I don't sell my
goods, I will be in trouble with the creditor. TraderMoni has reached our market but I think it's
for people with connection to politicians. I don't want to worry myself with that. Government
should give us money, not loans (Interview with a market leader [F] aged 50, 21/10/19).

From the Pearson chi-square result of 1.08 ( $\mathrm{p}$-value, 0.299 ), we conclude that there is no significant relationship between collection of loan and gender while there is a significant relationship between loan collection and housing as depicted by the Pearson chi-square result of 35.5 (p-value, 0.000). Houseowners approach the microcreditmarket more than tenants to take loans since they have assets useable as collaterals. However, although houseowners are fewer than tenants, the proportion of houseowners who had collected loans (21.0 per cent) is higher than that of tenants who also collected loans (8.1 per cent).

Table 3. Gender, Housing and Propensity to Taking Loans

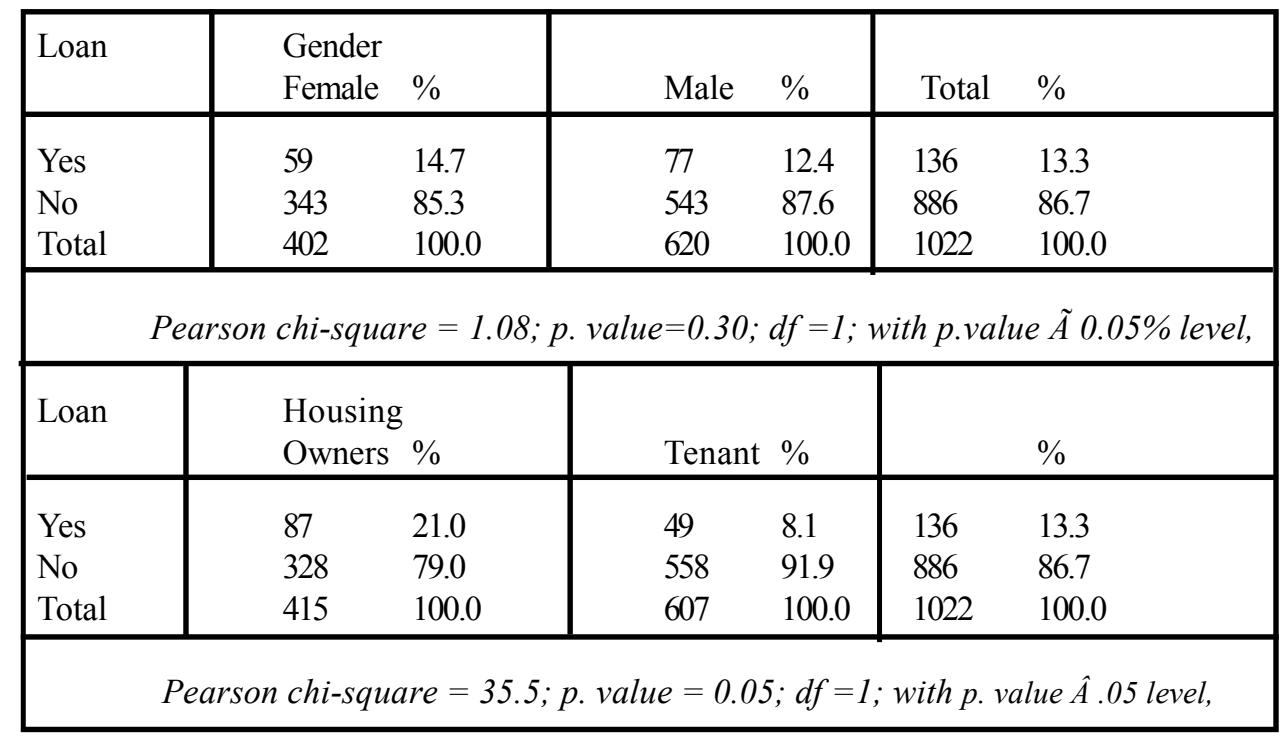

If availability of credit from local networks explains the apparent pervasive aversion to formal loans by all categories of people in the study sample, it may be a moot point to suggest that tenants, artisans, teachers or traders miss the opportunity to create more wealth. Even so, aversion to formal microcredit defeats government objectives, that is, to create wealth and facilitate the breakout from low income and poverty. In other words, although inability of respondents to take such loans 
Intersectionality, Relativity and Multiple Deprivation in Upper Saponba Area, Benin City, Nigeria 100

may be said to represent a loss of opportunity, we need to be careful in concluding that rejection of formal microcredit impugns the proverbial versatility of Nigerian market women. In fact, the point of view of respondents suggests the effectiveness of local alternatives over formal microcredit and an apparent distrust of government. Therefore, respondents appear justifiably fixated on their usual patterns of existence and survival.

\section{Health behaviour}

Our intention here is to discover any link between poverty and the health behaviour of respondents following the presumption that low socioeconomic status and poverty are associated with lower levels of health (Aue and Roosen, 2010). Health behaviour, usually a synonym for preventive health behaviour, may be preventive, protective or health-seeking. An individual could be categorised as belonging to a high-risk group depending on genetic, behavioural or socioeconomic characteristics. In cardiovascular disease, risk may arise from somatic, behavioural and strain factors (Amzat and Razum, 2014). In this study, our attention is focused on three popular and visible behaviours: smoking, lack of exercise and alcohol consumption. These are part of the six-health behaviour inventory analysed by Awabil and Anene (2018). The essence of our analysis here is to decipher the habits of slumdwellers and consider if the fatalism that may be inhered in their health behaviour is attributable to environmental or other factors.

A total of 67.0 per cent of the study sample is consisted by smokers, an unhealthy habit associated with many fatal ailments. Similarly, 86.8 per cent of the sample is consisted by alcohol consumers, harmful health behaviour. These poor habits are worsened by the fact that only 11.4 per cent indicated participation in physical exercise. Among the smokers, 79.7 per cent had up to five sticks of cigarette daily while the rest consumed more. On the other hand, 56.4 per cent of the alcohol consumers took some every day while 22.5 per cent did so every other day. The rest indicated weekly consumption. With respect to physical exercise, only about 4.0 per cent of those who participated partook in competitive sports, while the rest are involved in recreational sports.

\section{Income status and smoking}

Data presented in Table 4 indicate that the lower the income, the higher the incidence of smoking. A total of 95.2 per cent of respondents who smoke belong among low-income earnerswhile18.1 per cent of non-smokers belong to the high-income group. The Pearson chi-square value of 47.7 shows that there is a significant relationship between income and smoking. This suggests that high-income earners are very likely not to smoke considering the proportion of those who do not smoke (18.1 per cent) and those who smoke (4.8 per cent).

Indeed, smoking is a vice usually associated more with poor people. As confirmed by Greenhalph et al. (2020), Hosseinpoor et al. (2012), poor people and those with little or no education are more likely to smoke. Ominously, 80 per cent of all smokers are domiciled in low- and middle-income countries. Moreover, according to Action on Smoking and Health (ASH, 2019), the costs of 
smoking push people into poverty just as tobacco-related harm for people is a significant social inequity in Europe (Loring, 2014).

Table 4: Income, Exercise and Propensity to Smoke

\begin{tabular}{|c|c|c|c|c|c|c|}
\hline Income & No & $\begin{array}{l}\text { Smoke? } \\
\%\end{array}$ & Yes & $\%$ & Total & $\%$ \\
\hline High & 61 & 18.1 & 33 & 4.8 & 94 & 9.2 \\
\hline Low & 276 & 81.9 & 652 & 95.2 & 928 & 90.8 \\
\hline Total & 337 & 100.0 & 685 & 100.0 & 1022 & 100.0 \\
\hline \multicolumn{7}{|c|}{ Pearson chi-square $=47.7 ; p$. value $=0.05 ; d f=1 ;$ with $p$. value Â.05 level } \\
\hline \multirow[t]{2}{*}{ Income } & \multicolumn{6}{|c|}{ Exercise? } \\
\hline & No & $\%$ & Yes & $\%$ & total & $\%$ \\
\hline High & 59 & 6.5 & 35 & 29.9 & 94 & 9.2 \\
\hline Low & 846 & 93.5 & 82 & 70.1 & 928 & 90.8 \\
\hline Total & 905 & 100.0 & 117 & 100.0 & 1022 & 100.0 \\
\hline
\end{tabular}

\section{Income status and exercising}

With respect to involvement in physical exercise, there is a somewhat inverse relationship. For example, 29.9 per cent of all respondents is constituted by high-income earners who are involved in physical exercise. The remainder (70.1 per cent) are low-income earners. These distributions hardly distract from the well-established fact that a majority of all categories of respondents do not participate in physical exerciseor that a disproportionate majority of respondents are low-income earners. The Pearson chi-square result is 67.9 (p-value, 0.000 ) which shows that there is a significant relationship between high-income and exercise. This suggests that those with low income find it difficult to exercise. We may attribute this to the general economic hardship in the country whereby people spend more time trying to eke out a living, at the expense of exercising.

Undeniably, there is growing evidence that income status tends to determine physical activity (Economic and Social Research Council[ESRC], 2014; Kim and So, 2014; Romero, 2005; Matthew, 2000). Among the factors implicated are safety of the environment and availability of facilities. The dire safety situation in USa is perhaps the most unedifying characteristic of the area. On the issue of facilities, there are no open spaces, sports centres or public fields in the area. Fields inside public educational institutions are either inaccessible or inadequate for any meaningful physical or sporting activity. None of the private educational institutions in USa has any fields or open spaces. For those who may wish to jog, the roads are most inappropriate, being either waterlogged, unsafe, too narrow or too busy. Of course, the major thoroughfare, Upper Saponba Road is completely out of the question because of the internecine struggle between vehicular traffic, roadside traders, cart pushers, hawkers and pedestrians. 
Intersectionality, Relativity and Multiple Deprivation in Upper Saponba Area, Benin City, Nigeria 102

\section{Income status and alcohol consumption}

Further, we compared income data with data on alcohol consumption and discovered that more low-income earners took alcohol than high-income earners. A total of 85.8 per cent of all respondents indicated they consume alcohol. Of the low-income earners, 94.1 per cent take alcohol, of which 48.8 per cent did so every day. On the other hand, 75.5 per cent of high-income earners drank alcohol, of which 22.5 per cent did so daily. The proportion becomes even more significant if we consider that only 5.9 per cent of low-income earners does not takealcohol while 24.5 per cent of high-income earners doesnot. Although a majority of high-income earners ( 75.5 per cent) claimed it consumed alcohol, this makes up only 9.2 per cent of the total sample. Note also that $20.2 \mathrm{per}$ cent low-income earners who took alcohol did so weekly and 31.6 per cent did so weekly. It is only among high-income earners that we have a minority of 22.5 per cent taking alcohol daily while 28.2 per cent consumed every other day. A majority of 47.9 per cent of high-income alcohol consumers took it weekly. Therefore, low-income earners appear to be more involved than highincome earners in terms sheer numbers and regularity of alcohol consumption, a cause of multifarious social and health complications (Jones and Sumnall, 2016; Karriker-Jaffe et al., 2013).

\section{Education and propensity to smoke}

How does the educational qualification of our respondents intersect with their health behaviour? Among the smokers in our sample, 80.9 per cent was constituted by lowly educated people while highly educated respondents made up only 14.2 per cent. The association between smoking and education gives credence to the idea that people with lower education may be more fatalistic in their health behaviour. Earlier findings underscore this relationship. In a large-scale study covering 30 African countries, it was found that higher educated people smoked less (Sreermareddy et al., 2014). No education or lower educational qualifications tie people to low socioeconomic status, a station in life that is conducive to fatalistic health behaviour. Data from studies in Brazil and Europe confirm that people with lower educational qualifications tend to smoke more (Justus et al., 2020; Feinsteinet al., 2006) while in the United States, findings from national surveys indicated that people with lower educational qualifications found it more difficult to quit smoking (Zhuang et al., 2015).

If smoking and alcohol consumption are unhealthy habits associated more with persons of low educational status, we should add that such persons are also less involved in exercising which is specifically recommended as a healthy behaviour. Although a majority of all respondents do not engage in any physical exercise, many of those that partake belong among respondents with low educational qualifications. Considering that respondents with low educational qualifications are also more involved in alcohol consumption, our data seem to conclusively establish that people with lower education tend to engage more in unhealthy habits. 


\section{Infrastructure deficit}

Perhaps the most explicit manifestation of intersectionality in USa is the deficit in municipal infrastructure and urban services. It is an integral part of Benin City, an afropolis notorious for these deficits (Okolocha, 2014). Founded during the colonial era, the afropolis mushroomed into an over-urbanised nonindustrial modern city marked out by severe shortages in services and infrastructure as well as poverty, unemployment and a dominant informal economy. Probably, the debauched afropolis is the most daunting challenge facing Africa in the urban century.

Table 5: Municipal services/infrastructure in USa $(\mathrm{N}=1022)$

\begin{tabular}{|l|l|l|l|}
\hline $\begin{array}{l}\text { Urban Services/ } \\
\text { infrastructure }\end{array}$ & $\begin{array}{l}\text { Public/private } \\
\text { provision \% }\end{array}$ & None \% & Remarks \\
\hline Water supply & $37.2^{*}$ & 62.8 & $*$ Borehole \\
Electricity supply & $97.0^{* *}$ & 3.0 & $* *$ Connection \\
Waste disposal & $22.7^{*}$ & 77.3 & $*$ Contractor \\
Toilet type & $67.8 \dagger$ & $32.2 \dagger \dagger$ & $\dagger$ †C ††Pit \\
Drainage & 32.6 & 67.4 & \\
\hline
\end{tabular}

Table 5 shows the poor state of municipal services and infrastructure in the study area. It is easily observable that houses are built with durable materials. Water supply is the biggest municipal problem with 37.2 per cent of study respondents depending on private boreholes. The majority (62.8 per cent) does not have public water supply as they depend on commercial boreholes, well water, rainwater and "pure water" (that is, packaged sachet water). Water from these sources is largely raw as even "pure water" may be untreated. Drinking such waters may be responsible for unspecifiable waterborne diseases and a source of grave illness (Parvez et al., 2019; KimaniMurage and Ngindu, 2007). Inability to provide public potable water is possibly the most potent failure of governance in USa.

Electricity supply is equally debilitating although a vast majority of 97.0 per cent of respondents' houses are connected to the public electricity grid. Such connections rarely translate to supply. Electricity deficit is a national calamity in Nigeria with consumers going several days, weeks or months without supply from the various regional electricity distribution companies. According to a civil servant who is also a tenant:

BEDC (Benin Electricity Distribution Company, the local electricity provider) does not pay attention to us. We report to them regularly about power outages but they don't do anything. I don't have the modern prepaid meter because it is not available, so I receive an estimated bill every month even when there is no supply of electricity. Last year, our transformer exploded and we contributed money to repair it; yet there is hardly any supply. My landlord has a generator for his apartment but he lights up the compound at night when it is switched on. I don't complain about the noise of the generator because I will buy one when I have money (Interview with a tenant [M], aged 41, 11/07/19). 
Intersectionality, Relativity and Multiple Deprivation in Upper Saponba Area, Benin City, Nigeria 104

For 3.0 per cent of the respondents who are not connected to the electricity grid, action to achieve that is only being awaited. According to an affected respondent, the delay is a function of financial constraints as consumers are required to provide electricity poles, conductor cables and sundry materials required by the electricity distribution company to facilitate customer connection. Such expenditure borne by consumers are never refunded.

Only 22.7 per cent of all respondents receive the paid services of waste collectors who are contractors registered by government. Although these contractors ought to collect wastes regularly from their clients, this is rarely the case and individual compound dumps may fester for indefinite periods of time. Waste collection (or management) is a constitutional local government function but, due to technical, financial and institutional incapacity, has been totally abdicated. The function has been unduly taken-over by state governments (World Bank, 2017; Uchendu, 2016; Amudu et al., 2014; Adama, 2007), a usurpation justified by the contrived incapacity of local governments but has not yet been legalised through constitutional amendment. Ironically, state governments are also unable to carry-out the function and have therefore outsourced it to contractors (who are not known for any efficiency).

Waste management in USa is limited to ineffective and occasional waste collection in a few compounds although a limited recycling of plastic and metals is carried out by a nearby privateforeignownedcompany. All forms of wastes collected by the licensed collectors are deposited at the official dumpsite. Most individuals merely throw their wastes at the ubiquitous roadside dumps or the backyard of households, the option available to 77.3 per cent of our study sample. The official waste dumps are far from the study area but they are never treated and are therefore perfect habitat for disease-bearing rodents and other vectors including the ubiquitous mosquito. Recently, itinerant metal waste and plastic collectors have joined the sector and they could be seen in every part of USa with their pushcarts.

Probably due in part to the scarcity of water, 32.2 per cent of the sample does not have watercloset (wc) toilets and therefore use odoriferous pit latrines usually annexed to backyards. However, a majority of 67.8 per cent has access to wc toilets within their houses. Considering that 62.8 per cent of the respondents depends on wells, commercial boreholes, rain and "pure water", this is evidence of a commendable effort to use a modern toilet facility. Further on public hygiene, only 32.6 per cent of the study sample is served by public drainage channels by roadsides. Indeed, everywhere else outside Upper Sakponba Road is liable to flood, an annual scourge during the long rainy season beginning from the month of March and ending in October.

Let us consider how the different income groups fare with respect to the deficits in urban infrastructure and services. 


\section{Income status, water and electricity supply}

In Table 6a we see clearly that of the two income categories, low-income earners are at a very cockeyed disadvantage with respect to watersupply. For example, with all low-income respondents not having potable water in their houses, the implication is that they have to devote a considerable part of their income procuring water for drinking and other uses. All high-income earners have water supply through boreholes in their premises. Consumption of raw/untreated water from rainfall, boreholes and wells is guaranteed to expose consumers to diseases associated with dirty water such as typhoid fever, cholera, etc.

With respect to electricity supply, there is evidence of connection to the public electricity grid among a majority of respondents across income lines. As shown in Table 6a, it is only among lowincome earners that we have a few households without connection to the electricity grid. As connection to grid does not guarantee electricity supply, we have to exercise a measure of incredulity in accepting such genial statistic. According to a senior civil servant in the area:

I get more electric power supply from my generator which now consumes a lot of fuel because it is very old. I run the generator every day as there is always no supply from BEDC. Nobody is sure when there will be electricity and we can go through weeks without supply; and nobody gives you any reason for the constant power failure. In some days, when I pump water, I spend up to three thousand naira to buy fuel for my generator. If you add this to the estimated bill I pay monthly, you will see that electricity takes a big chunk of my salary (Interview with a civil servant [M], aged 52, 11/07/19).

Table 6a. Income, Water and Electricity Supply

\begin{tabular}{|c|c|c|c|c|c|c|c|c|}
\hline \multirow{2}{*}{ Income } & \multicolumn{4}{|c|}{ Water } & \multirow[b]{2}{*}{ None } & \multirow[b]{2}{*}{$\%$} & \multirow[b]{2}{*}{ Total } & \multirow[b]{2}{*}{$\%$} \\
\hline & \multicolumn{2}{|l|}{ Borehole } & \multicolumn{2}{|l|}{$\%$} & & & & \\
\hline High & 94 & & 24.5 & & 0 & 0 & 94 & 9.2 \\
\hline Low & 290 & & 75.5 & & 638 & 100 & 928 & 90.8 \\
\hline Total & 384 & & 100.0 & & 638 & 100.0 & 1022 & 100.0 \\
\hline \multicolumn{9}{|c|}{ Pearson Chi-square $=172.0 ; p$. value $=0.05 ; d f=1 ;$ with $p$. value $\hat{A} .05$ level } \\
\hline Income & \multicolumn{4}{|c|}{ Electricity } & $\%$ & & \multicolumn{2}{|l|}{$\%$} \\
\hline High & 0 & 0 & & 94 & 9.5 & 94 & 9.2 & \\
\hline Low & 31 & 100 & & 897 & 90.5 & 928 & 90.8 & \\
\hline Total & 31 & 100.0 & & 991 & 100.0 & 1022 & 100.0 & \\
\hline
\end{tabular}

In our cross-tabulation of income, water and electricity supply in Table 6a, the Pearson chi-square result of 170.0 ( $\mathrm{p}$-value, 0.05 ) for income and water supply indicates that there is significant 
Intersectionality, Relativity and Multiple Deprivation in Upper Saponba Area, Benin City, Nigeria 106

relationship between them. This means that high income earners are always able to own boreholes hence only rich people are theones having borehole water supply in the community. On the contrary, the result for income and electricity supply shows that there is no significant relationship between income and electricity with the Pearson chi-square value of 3.24 ( $\mathrm{p}$ value, 0.072 ). This can be attributed to the fact that both the rich and poor make use of public electricity.

\section{Income status, toilet type and access to drainage}

In Table $6 \mathrm{~b}$, we see that a total of 86.4 per cent of low-income earners have wc toilet facility in their houses and, because of the availability of water, it was not unexpected that all high-income respondents had wc toilet facility. The Pearson chi-square result of 49.2 (p-value, 0.000 ), suggests that there is a significant relationship between income and the type of toilet used in the community. A total of 13.6 per cent of the sample which makes up the high-income earners use wc toilet facility while none this income group used pit latrines. On the other hand, all those who used pit latrines are low-income earners. Therefore, a high-income gives the individual in the community an opportunity to use a decent (modern) toilet.

Table $6 \mathrm{~b}$. Income, toilet type and access to drainage

\begin{tabular}{|c|c|c|c|c|c|c|}
\hline \multirow[t]{2}{*}{ Income } & \multicolumn{6}{|c|}{ Type of toilet } \\
\hline & Pit & $\%$ & Wc & $\%$ & Total & $\%$ \\
\hline High & 0 & 0.0 & 94 & 13.6 & 94 & 9.2 \\
\hline Low & 329 & 100.0 & 599 & 86.4 & 928 & 90.8 \\
\hline Total & 329 & 100.0 & 693 & 100.0 & 1022 & 100.0 \\
\hline \multicolumn{7}{|c|}{ Pearson Chi-Square $=49.15 ;$ p. value $=0.05 d f=1 ;$ with $p$. value $\hat{A} .05$ level } \\
\hline \multirow[t]{2}{*}{ Income } & \multicolumn{6}{|c|}{ Drainage } \\
\hline & Public & $\%$ & None & $\%$ & Total & $\%$ \\
\hline High & 79 & 23.7 & 15 & 2.2 & 94 & 9.2 \\
\hline Low & 254 & 76.3 & 674 & 97.8 & 928 & 90.8 \\
\hline Total & 333 & 100.0 & 689 & 100.0 & 1022 & 100.0 \\
\hline
\end{tabular}

On the other hand, with respect to income and access to drainage facility, the Pearson chi-square result of 124.8 ( $p$-value, 0.000 ) shows that there is a significant relationship between both variables. The table shows that among those who do not have access to drainage facility, 97.8 per cent is made up by low-income earners who are thereby exposed to the intensity and severity of floods every year. Similarly, among those who have access to drainage, $76.3 \%$ are also low-income earners. The result may seem contradictory, yet it is valid because drainage is a governmentprovided facility. Therefore, every household is entitled to it as the drains are constructed to protect the roads and community without reference to proximity of the homes of the rich or poor. 
Toilet type and connection to the electricity grid are the only parameters which featured a majority of all respondents across all income categories, though we should be careful to observe that lowincome earners make up over half of the total respondents of the study.Unlike connection to the public electricity grid, there is considerable significant disparity in the type of toilet owned by people with low and high educational qualifications. Whereas 93.8 per cent of respondents with high educational status had wc toilets, the proportion is 69.6 per cent for those with low educational qualifications.

In view of the fact that respondents with low educational qualifications formed the majority of our sample, it is obvious that public sanitation is still lagging in USa because as much as 30.4 per cent of their members still uses unsanitary pit latrines.

\section{Education and infrastructure deficit}

Given the well-established nexus between poverty and education (see, e.g., Mihal et al., 2015; Pervez, 2014; Buck and Deutsch, 2014; Awan et al., 2011; Rose and Dyer, 2008; Palmer et al., 2007), it is important to examine how the educational status of our study respondents intersect with their access to municipal utilities. The data of the study seem to point to certain directions in tandem with general trends already established

For example, a total of 85.0 per cent of respondents with low educational attainments, that is, those with no education, primary or secondary educational qualifications, did not have boreholes or better water supply in their premises. This compares very unfavourably with the 84.0 per cent of respondents with high educational qualification who had borehole water supply in their premises, implying that people with higher educational qualifications tend to put more premium on this urban utility, bearing in mind that they are perhaps economically better off.

Although borehole water supply may not be equated with public potable water, it may presumably be of higher quality than well or rainwater. Going by the hypothesis that poverty coheres with low or no education, it is equally arguable that quality of water improves with educational qualification. Conversely, our data show that while 15.0 per cent of respondents with low educational qualifications had borehole water supply, 16.0 per cent of those with high educational qualification also had no such facility. Even so, the total absence of public piped potable water in USa is one of the parameters that justifies the classification of the area as a slum, the home of the poor in the city.

Table 7a. Educational status and drainage access

\begin{tabular}{|l|ll|llll|}
\hline Education & Public & $\%$ & None & $\%$ & Total & $\%$ \\
\hline High & 263 & 79.0 & 74 & 10.7 & 337 & 33.0 \\
Low & 70 & 21.0 & 615 & 89.3 & 685 & 67.0 \\
Total & 333 & 100.0 & 689 & 100.0 & 1022 & 100.0 \\
\hline
\end{tabular}


Intersectionality, Relativity and Multiple Deprivation in Upper Saponba Area, Benin City, Nigeria 108

Table 7a shows the cross-tabulation of the educational status of our respondents and their access to drainage facility. The Pearson chi-square result of 473.0 (p-value, 0.000 ) shows that there is a significant relationship between education status and drainage. It can be seen that 79.0 per cent of those with access to public drainage system are highly educated people while 89.3 per cent of those who do not have access respondents with low educated status. The strong relationship between educational attainment and access to drainage cannot be merely coincidental.

With respect to electricity supply, our data has already indicated that a majority of respondents were connected to the public electricity grid even though such connection did not translate to electric power supply. The Pearson chi-square value of 15.7 (p-value, 0.000 ) indicates that there is a significant relationship between education and electricity supply (see Table 7b). However, the result shows that 66.0 per cent of those with connection to public electricity grid have low education while 34.0 per cent are highly educated which seem to suggest that low education attracts better connection to public electricity grid. This is not the case as there is no high-income household without connection. Electricity is a public good largely provided to all individuals in the community. However, there area lot of illegalities in both the supply and usage of electricity in the country as whole.

On waste disposal, the Pearson chi-square result of 384.8 (p-value, 0.000 ) shows that there is a significant relationship between education status and waste collection. As shown in the table, 86.2 per cent of the respondents whose wastes are collected are those with high education while82.7 per cent of those whose wastes are not collected are of low educational status. This suggests that education status has significant relationship with waste disposal and, therefore, it is arguable that people with high education seem to invest more in public health than those with low educational qualifications. We should however exercise some circumspection in accepting this deduction because a significant proportion of highly educated respondents (17.3 per cent) belongs among those whose wastes were not collected. Being a slum area, residents may not consider investment in waste collection a priority. Moreover, waste collection or management is a public issue and the obvious nonchalance of government on the matter is a critical disincentive to slum dwellers.

Table 7b. Education, Electricity Supply, Waste

\begin{tabular}{|l|lllll|ll|}
\hline Education & \multicolumn{9}{|c|}{ Electricity } & Total & $\%$ \\
& None & $\%$ & Public & $\%$ & 337 & 33.0 \\
\hline High & 0 & 0.0 & 337 & 34.0 & 685 & 67.0 \\
Low & 31 & 100.0 & 654 & 66.0 & 1022 & 100.0 \\
Total & 31 & 100.0 & 991 & 100.0 & \\
\hline
\end{tabular}

Pearson Chi-square $=15.73 ;$-value $=0.05, d f=1 ;$ with $p$. value Â.05 level 
109 Annals of the Social Academy, Nos. 22, Jan.-Dec., 2018/2019

\begin{tabular}{|l|lllll|ll|}
\hline Education & \multicolumn{9}{|c|}{ Waste disposal } & Total & $\%$ \\
& None & $\%$ & Public & $\%$ & & 337 & 33.0 \\
& 137 & 17.3 & 200 & 86.2 & 685 & 67.0 \\
High & 653 & 82.7 & 32 & 13.8 & 1022 & 100.0 \\
Low & 790 & 100.0 & 232 & 100.0 & \\
Total &
\end{tabular}

Pearson Chi-square $=384.8 ; p$. value $=0.05, d f=1 ;$ with $p$. value $\hat{A} .05$ level

\section{Insecurity}

Insecurity is at the centre of national discourse because of insurgency, terrorism, banditry, abduction and other forms of crime that have become rampant in Nigeria in the $21^{\text {st }}$ century (Onime, 2018; Otolorin, 2017; Ewetan and Urhie, 2014). The notoriety of our data universe maybe owed to insecurity more than any other intersecting parameter. Data in Table 8 capture the experience and perception of insecurity in USa.

On the general perception of public safety, an overwhelming 97.0 per cent indicated that USa is unsafe. This is in tandem with the general stereotype, which appears justified by our data. For example, a total of 60.6 per cent of the respondents indicated they or their neighbours had been robbed, while 76.6 per cent claimed awareness of the activities of internet syndicates popularly known as "yahooboys," who are notorious for defrauding people through online transactions. Probably because of this awareness, none of the respondents had ever fallen victim to these scammers. As they operate covertly from private homes or business centres, "yahoo boys" may overtly not be a security threat especially as their victims may be far from the scene of crime; yet these youths constitute a social menace because of their unsustainable lifestyles.

Because of the pervasive negative perception of public safety, you would expect many reports at the police station, but 79.5 per cent of the respondents had not had cause to report to the police even when 80.4 per cent of them claimed to have witnessed a robbery and 60.6 per cent had actually been robbed. This is probably because 87.0 per cent of the respondents felt that the police had not been useful to them. Part of this negative perception may also be due to the fact that 91.9 per cent of the respondents said that USa is not patrolled by the police and 56.6 per cent had not witnessed any arrests by the police.

If "yahoo boys" are discrete and covert operators, not so for "cult boys", another category of violent youths whose night trysts have now spilled over into daytime. A total of 87.7 per cent of respondents knew of the activities of "cult boys." Possibly because of the combined effects of activities of "yahoo boys" and "cult boys" among others, a total 97.8 per cent of the respondents felt that USa is unsafe at night while 76.0 per cent hoped to relocate from the area in future. 
Intersectionality, Relativity and Multiple Deprivation in Upper Saponba Area, Benin City, Nigeria $\quad 110$

Table 8: Experience of insecurity $(\mathrm{N}=1022)$

\begin{tabular}{|l|l|l|}
\hline Perception of safety & Yes \% & No \% \\
\hline Upper Saponba is safe & 3.0 & 97.0 \\
I have been robbed in the street & 7.0 & 93.0 \\
I have lost my telephone handset to thieves & 21.0 & 79.0 \\
My house/neighbour has been robbed & 60.6 & 39.4 \\
Somebody has been killed around here & 1.1 & 98.0 \\
"Yahoo boys" operate around here7 & 6.6 & 23.4 \\
The police is usefull & 3.0 & 87.0 \\
Police officers patrol this area & 8.1 & 91.9 \\
Police officers have arrested someone around here & 43.4 & 56.6 \\
I have reported a suspect to the police & 20.5 & 79.5 \\
We have a vigilante group in my street & 86.9 & 13.1 \\
I have witnessed armed robbery in this area & 19.6 & 80.4 \\
It is not safe at night & 97.8 & 2.2 \\
I hope to leave this area & 76.0 & 24.0 \\
I have been kidnapped before & 0.4 & 99.6 \\
I know someone who has been kidnapped & 20.8 & 79.2 \\
I have been confronted by armed herdsmen & 2.6 & 97.4 \\
Herdsmen have killed someone in this area & 5.5 & 94.5 \\
"Cult boys" are active in this area & 85.7 & 14.3 \\
Cult boys have killed someone around here & 20.7 & 79.3 \\
Women are raped regularly & 19.1 & 80.9 \\
I know someone who has been raped & 3.0 & 97.0 \\
\hline
\end{tabular}

However, these negative perceptions may be an over-simplification of reality as the evidence from our data do not present a picture of complete anarchy or anomie. For example, contrary to what we should expect from such perception, 83.0 per cent of the respondents had never been robbed in the streets and only 21.0 per cent had lost their telephone handsets to thieves. We should note that among the latter, we have people who may have lost their handsets through misplacement and would certainly not be justified if they blamed thieves. Next, even if 60.6 per cent of the respondents indicated that they (or their neighbours) had been robbed in the past, only 1.1 per cent of the respondents knew of any murder in USa.

Further, a total of 86.9 per cent said that local vigilante groups operated in their area. This should ensure some security and an overwhelming majority of 99.6 per cent of our respondents had not been kidnapped, thus negating the folklore of kidnapping which propagates the rampancy of kidnapping. In addition, 79.2 per cent of the respondents did not know anyone who had been kidnapped while 97.4 per cent had not been confronted by itinerant herdsmen. And in spite of the 
murderous notoriety of herdsmen, 94.5 per cent of our respondents had not heard that they killed anyone in the neighbourhood while none of them knows anyone who had been killed by herdsmen. The aura of insecurity is further negated by the fact that 79.3 per cent of the respondents had not heard of any killing by "cult boys" in the area while 80.9 per cent said women were not raped regularly as feared. In fact, 97.0 per cent did not know anyone who had been raped at the time of study.

\section{Income, perception of security and experience of crime}

Using income as an indicator of socioeconomic status, we examined the perception of our respondents on public safety and the police as well as their experience of crime, awareness of the activities of "cult boys" and the prospects of relocation of residents away from the area.

Data in Table 9a show that although there was an overwhelming sense of insecurity, this was more so among low-income earners where all members expressed a negative perception. We also see that among those who perceive that they are secured, 64.5 per cent are high-income earners while of those who feel insecure, 92.5 per cent are low-income earners, thus confirming the suggestion that the high-income earners feel more secure than low-income earners in the community.

Table 9a. Income, Perception of Security and Experience of Crime

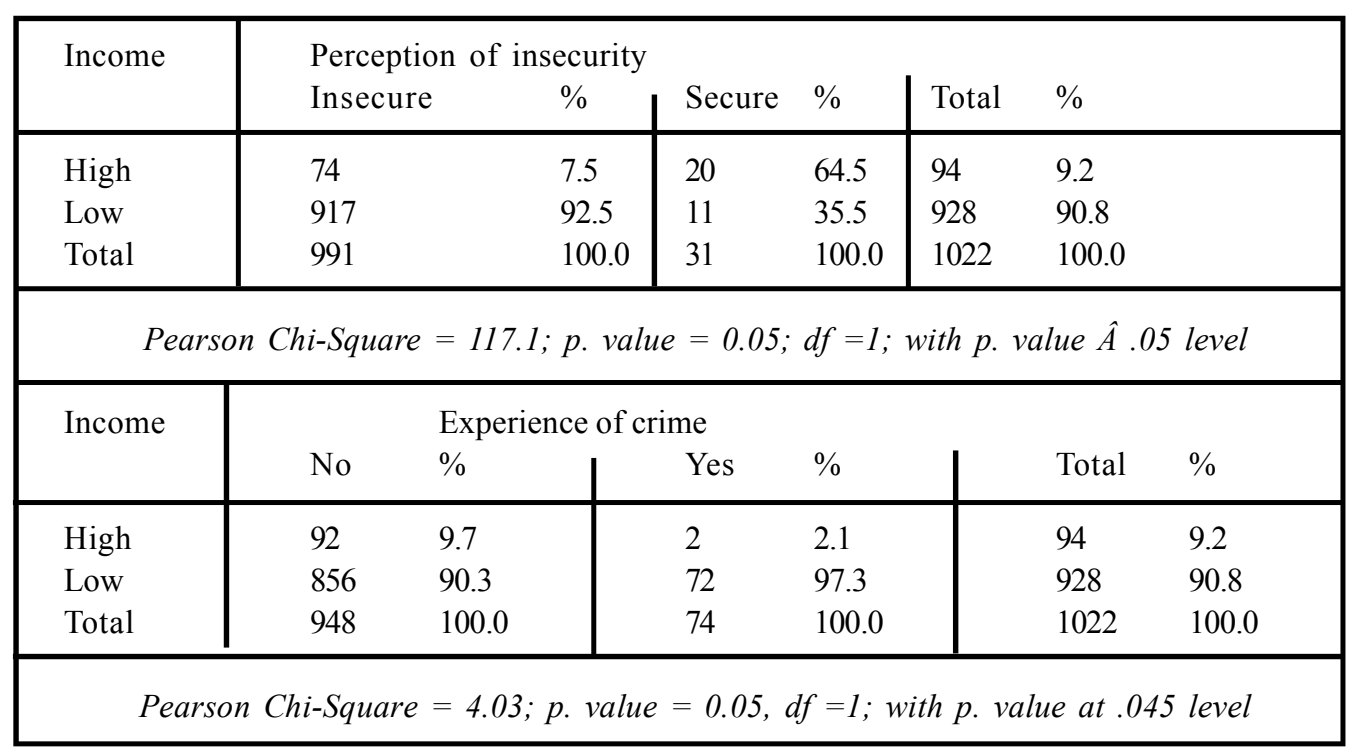

We may surmise from these data that well-off respondents were in a better position to ensure their own security. The Pearson chi-square value of 117.1 (p-value, 0.000 ) shows that there is a significant relationship between income level and perception of insecurity. On the other hand, with respect to the interconnection between income status and experience of crime, the Pearson chi-square result of 4.03 ( $\mathrm{p}$. value $=0.045$ ) shows a rather weak relationship. This is because both the high- and low-income earners have experienced crime situations in the community. 
Intersectionality, Relativity and Multiple Deprivation in Upper Saponba Area, Benin City, Nigeria $\quad 112$

An insightful study by Cuthbertson (2018) showed that the poor are not only most likely to be victims of crime but also lived in fear of it more anyone else, while the classic work by Reiman and Leighton (2016) confirm their assertion that in the crime nexus, "the poor goes to prison as the rich get richer," a euphemism for the security challenges of the poor. The relationship between poverty and crime in the slum is never straightforward because poorer segments which are more likely to be victims are also the most likely to be held responsible for crime (Moser et al., 2005).

\section{Income, awareness of "cult boys" and perception of police}

There is a somewhat inverse relationship when we consider the issue of awareness of activities of "cult boys" (Table 9b). The data show that 89.3 per cent of the total sample which indicated their awareness of the activities of cult boys are low-income earners while no high-income earner was unaware. Consequently, all those who claimed not to be aware were low-income earners, but their number are very small when compared to those who claimed awareness. The Pearson chi-square result of 17.25 (p-value, 0.000 ) shows that there is significant association between both of them. Therefore, low incomes earners seem to have more knowledge about the cult activities in the community.

Table 9b. Income, Awareness of Cult Activity and Perception of Police

\begin{tabular}{|c|c|c|c|c|c|c|}
\hline \multirow[t]{2}{*}{ Income } & \multicolumn{6}{|c|}{ Awareness } \\
\hline & No & $\%$ & Yes & $\%$ & Total & $\%$ \\
\hline High & 0 & 0.0 & 94 & 10.7 & 94 & 9.2 \\
\hline Low & 146 & 100.0 & 782 & 89.3 & 928 & 90.8 \\
\hline Total & 146 & 100.0 & 876 & 100.0 & 1022 & 100.0 \\
\hline \multicolumn{7}{|c|}{ Pearson Chi-Square $=17.25 ; p$. value $=0.05 ; d f=1 ;$ with $p$. value $\hat{A} .05$ level } \\
\hline \multirow[t]{2}{*}{ Income } & \multicolumn{6}{|c|}{ Perception of police } \\
\hline & $\begin{array}{l}\text { Not } \\
\text { Useful }\end{array}$ & $\%$ & Useful & $\%$ & Total & $\%$ \\
\hline High & 0 & 0.0 & 94 & 71.2 & 94 & 9.2 \\
\hline Low & 890 & 100.0 & 38 & 28.8 & 928 & 90.8 \\
\hline Total & 890 & 100.0 & 132 & 100.0 & 1022 & 100.0 \\
\hline
\end{tabular}

Similarly, among the respondents that say the police is useful 71.2 per cent are high income earners while among the respondents that do not see them as useful, 100.0 per cent are low-income earners. We may attribute the poor perception of the police by poor people as a function of poor police attitude toward them. If police has a better attitude toward the rich, then money is an incentive for the police. The Pearson chi-square result of 698.0 (p-value, 0.000) for income and perception of police, shows that there is a significant relationship between income and perception of police. 
Given the overall negative perceptions of our respondents on security, it is interesting that highincome earners are more committed to staying on in their present homes. A total of 92.6 per cent of persons in this category indicated a willingness to stay on in USa. This probably owes to the fact that high-income earners may own the houses in which they live. Family land is another factor rooting people to their residence in USa, a potent factor irrespective of income or any other status. Among the low-income respondents who said they will rather not relocate to other parts of Benin City are residents who customarily stay in their fathers' houses as first-born males or freebooters in the houses of relatives.

\section{Educational status and perception of security}

Finally, we examine the possible intersection between the educational qualifications of our respondents and their perceptions of security in the area. Table 10a shows the crosstabulation of educational status, perception of security and experience of crime in USa. Among the respondents that assert that they are insecure, 61.9 per cent is of low educational status, while among those who say they are secure, 100.0 per cent is of high educational status. We explain this to imply that education may be a source of awareness and enlightenment, enabling individuals to assert their rights, relate with the police and relate better with their environment. The Pearson chi-square of 64.98 (p-value, 0.05 ) shows that there a significant relationship between educational status and perception of security. Table 10a also shows the relationship between education and experience of crime. Among the respondents without experience of crime, 65 per cent is constituted by those with low education. Similarly, among those with experience of crime, 93.2 per cent is also of low educational status. Result of the Pearson chi-square is 24.81 ( $\mathrm{p}$-value, 0.05) implies that there a significant relationship between education and experience of crime in USa.The assertion of those with experience of crime may not be taken too seriously because their overall number is very small ( 74 respondents). Therefore, our conclusion is that that people of low educational status are not the target of criminals in the community.

Table 10a. Education, Perception of Security and Experience of Crime

\begin{tabular}{|c|c|c|c|c|c|c|c|c|}
\hline \multirow[t]{2}{*}{ Education } & \multicolumn{8}{|c|}{ Perception of security } \\
\hline & Insecure & $\%$ & \multicolumn{2}{|c|}{ Secure } & $\%$ & \multicolumn{2}{|l|}{ Total } & $\%$ \\
\hline High & 306 & 30.9 & 31 & & 100.0 & 337 & & 33.0 \\
\hline Low & 685 & 69.1 & 0 & & 0.0 & 685 & & 67.0 \\
\hline Total & 991 & 100.0 & 31 & & 100.0 & 1022 & & 100.0 \\
\hline \multicolumn{9}{|c|}{ Pearson Chi-Square $=64.98 ;$. value $=0.05 ; d f=1$; with $p$. value Â.05 level, } \\
\hline \multirow[t]{2}{*}{ Education } & \multicolumn{8}{|c|}{ Experience of crime } \\
\hline & No & $\%$ & Yes & $\%$ & 1 & Total & $\%$ & \\
\hline High & 332 & $\overline{35.0}$ & 5 & 6.8 & & 337 & 33.0 & \\
\hline Low & 616 & 65.0 & 69 & 93.2 & & 685 & 67.0 & \\
\hline Total & 948 & 100.0 & 74 & 100.0 & & 1022 & 100.0 & \\
\hline
\end{tabular}


Intersectionality, Relativity and Multiple Deprivation in Upper Saponba Area, Benin City, Nigeria $\quad 114$

There is also a clearly discernible relationship between level of education and public awareness of the activities of "cult boys" and perception of police as shown by the data in Table 10b. Among the respondents who indicated awareness, 61.5 per cent is of low educational background; likewise, all those without awareness are of low educational status. The Pearson chi-square result of 83.3 $(p$-value $=0.05)$ shows there is a significant relationship. This suggests that individuals with low educational status are more aware of cult activities in the community. Conversely, all highly educated respondents were aware of such activities but they make up only 38.5 per cent of the sample. Again, we attribute this to the preponderance of people with low educated status in our sample. However, our data generally point to high awareness by all respondents irrespective of educational qualifications.

The pattern on the awareness of the activities of "cult boys" is replicated on the question of public perception of the police. Among the respondents who perceive the police as not useful, 77.0 per cent is made up of individuals with low educational status while all those with a positive perception have higher educational backgrounds. The Pearson chi-square result of 308.1 (p-value, 0.05) in Table $10 \mathrm{~b}$ shows that there is a significant relationship between educational status and perception of police.Therefore, lowly educated individuals really do not see the need to rely on the services provided by the police authorities so much.

Table 10b. Education, Awareness of Cult Activity and Perception of Police

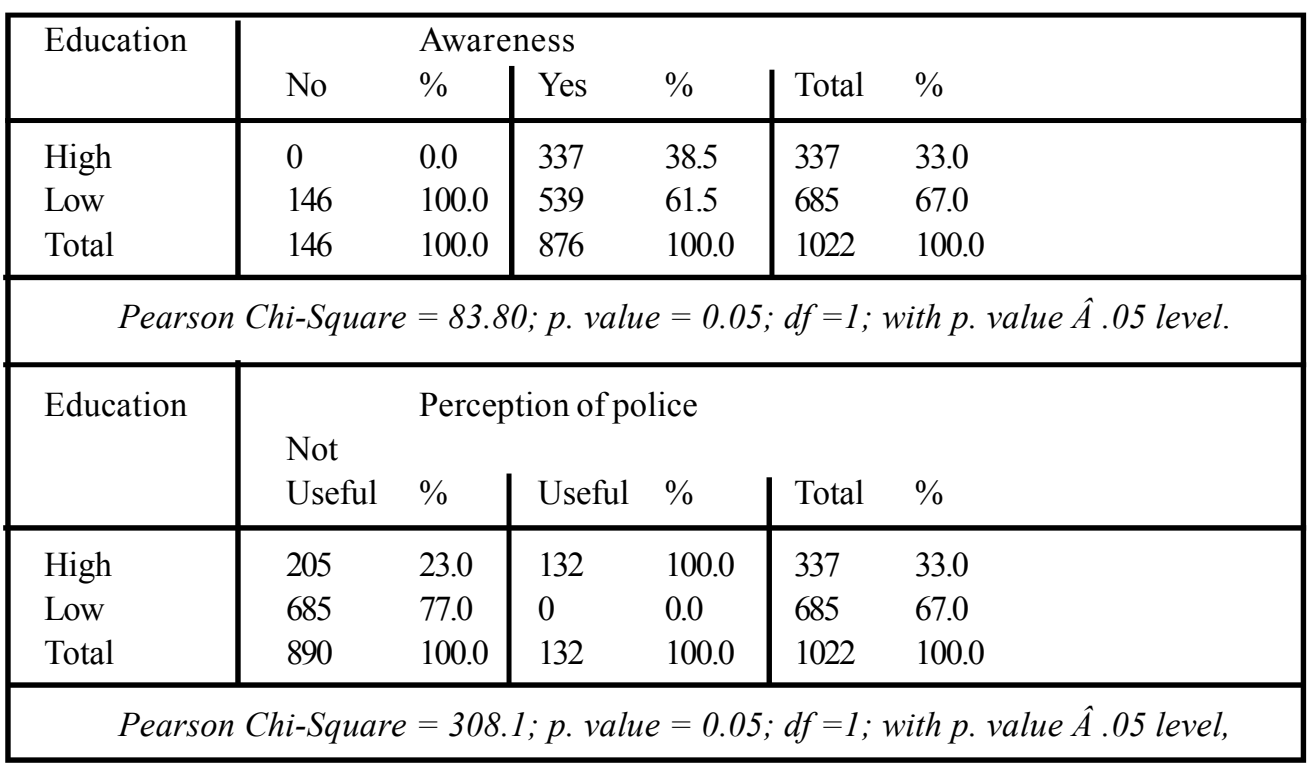

In Table 10c, we show the crosstabulation of educational status and the desire to relocate from the community. We can see in the table that among the respondents who have the desire to relocate away from USa, 86.2 per cent is constituted by those with low educational status while among those who say they would rather stay on, 93.9 per cent is composed by respondents with high educational background. We infer that educational qualification can influence a decision to stay or 
relocate from USa.The Pearson chi-square of 124.8 (p-value, 0.05) shows that there is a significant relationship between the two variables.Highly educated persons and high-income earners are more likely to prefer their current residences because they own them (or the land). They are also more likely to be adequately informed about the community and can adapt to its conditions. It may also mean that respondents do not want to relocate because USa is their ancestral quarter.

Table 10c.Education and Desire to Relocate from the Community

\begin{tabular}{|l|cc|cc|ll|}
\hline \multirow{2}{*}{ Education } & I will relocate \\
& Yes & $\%$ & No & $\%$ & Total & $\%$ \\
\hline High & 107 & 13.8 & 230 & 93.9 & 337 & 33 \\
Low & 670 & 86.2 & 15 & 6.1 & 685 & 67 \\
Total & 333 & 100 & 689 & 100 & 1022 & 100 \\
\hline \multicolumn{1}{|c|}{ Pearson Chi-Square $=124.8 ; p$. value $=0.05 ; d f=1 ;$ with $p$. value Â.05 level } \\
\hline
\end{tabular}

\section{Discussion and concluding remarks}

In the preceding sections, we used primary data in examining the intersection of several parameters of disadvantage and deprivation in USa. The purpose of the study is to show that slum dwelling cannot be understood in terms of one or two factors but a gamut of an infinity of factors which interpenetrate one another.

One heuristic deduction from our findings is the potency of relative deprivation. Whenever individuals compare themselves with better-off significant others and conclude that they do not deserve their disadvantage or determine that their share of material goods is unjust, we are confronted with relative deprivation (Smith and Huo, 2014). Arising from negative upward comparison, relative deprivation can possibly damage emotions, behaviour, mental and physical health. It may also impair inter- and intra-group attitudes and predispose people to joining protests (Smith et al., 2015).

The attitude of residents of USa betray profound alienation as they feel insecure and largely uncommitted to their environment. This is a function of their subjective judgement of better life elsewhere. Arising from this, youth subculture exemplified in USa by "yahoo boys" is interpreted as a fraudulent or criminal adaptation by unemployed young people to catchup with society and become rich, many of them imbued with the countercultural slogan of "get rich or die trying."

The subculture is facilitated by a society that places amoral premium on wealth and protection provided by the anonymity and freedom of the internet (Adejoh et al., 2019; Adeniran, 2008). In Nigeria, cybercrime and contemporary culture do not intersect with subtility; films and popular songs that shape the views of impressionable youngsters tend to reinforce the ritzy life of fraudsters and validate internet crime (Oloworekende, 2019). Thus, the concept of relative deprivation deepens our understanding of human behaviour and other social currents in the slum environment. 
Intersectionality, Relativity and Multiple Deprivation in Upper Saponba Area, Benin City, Nigeria $\quad 116$

Another issue thrown up by our findings is the probability of a culture of poverty arising from the response (or lack of response) of slumdwellers to incentives for bailing them out of poverty. Although our data point to a general apathy toward microcredit, this was more so among the low-income earners, less educated, unemployed and artisans. According the assumption of the culture of poverty hypothesis, this is a manifestation of self-exclusion and self-perpetuation in poverty as well as lack of agency. Yet the apparent rejection (inability or unwillingness) to accept formal microcredit needs not be interpreted as an action induced by a rootedness to old ways, for respondents had effective alternatives to what may be referred to as political microfinance. Loans available through microcredit do not seem to be superior to those available from traditional/informal channels (Murad and Idewele, 2017; Pomeranz, 2014; Khan, 2008; Swain, 2004; Lapenu, 2000). The latter are under-wired by group life and mechanical solidarity in which beneficiaries are equal participants committed to communal welfare. Over the years, these traditional channels have become very resilient probably because of the inherent transparency of transactions as there is no surplus value accruing to anyone. We therefore conclude that the behaviour of respondents is an adaptation as well as a reaction to their marginal status in the city, not an irrational consequence of the culture of poverty. In other words, it is a manifestation of the failure of government agency as well as a way of coping with hopelessness borne out their lived experience of great scarcity and failure to achieve success given the institutional barriers to inclusion.

In modern society, the alleged culture of poverty is adjudged to be a behavioural putdown and atavistic reaction to progress. Yet cultural resilience is not just a matter of economic deprivation or exclusion, nor is it merely an indicator of social disorganisation (or reorganisation). It is a (rational) response which fosters social solidarity and gives meaning to the life of the poor. As a middle-range theory, the culture of poverty tends to blame the victim as it holds that poverty begets poverty (Brady, 2019; Vossoughi and Rodela, 2018; Varenne and Scroggins, 2015; Davis and SanchezMartinez, 2014). In view of the inherent mobility aspirations of the urban poor and their daily struggles to eke out a living, the culture of poverty may not represent their accepted way of life. Further, the culture of poverty is silent on the other party to poverty, namely, the rich and privileged. Poverty is not a choice freely made. Indeed, the exclusion of the urban poor is not exclusive of the inclusion of the urban rich.

Our findings also throw up the grave question: is the fatalism intrinsic in the health behaviour of the urban poor a manifestation of the alleged culture of poverty? The parameters of poor health behaviour examined in this study include smoking, alcohol consumption and physical exercise. Findings showed that although there was generally poor health behaviour among all respondents, this was more so among those with lower income and lower educational qualifications. Since such poor health behaviours may be transmitted inter-generationally, they may be said to constitute part of culture. However, what is more important is that poor health among the urban poor directly negate the benefits of urban living and constitute a huge "urban penalty" paid by the poor (Satterthwaite, 2011; Sverdlik, 2011; Nelly et al., 2011). Therefore, the fatalistic health behaviour of slums dwellers is environmentally determined and an inevitable outcome of living in poverty. 
By definition slums are not just areas for poor people, but areas marked out by poor infrastructure and services. The provisioning of infrastructure enhances the capacities of the local populations and community, thereby establishing a direct relationship between infrastructure and development or between lack of provisioning and being left behind (UNDP, 2018). In this study we focused only on infrastructure in public and private space, namely, water and electricity supply, waste disposal, toilet type and drainage. Findings are generally consistent with earlier research onthe so-called culture of poverty and the health behaviour of our respondents (for analogous analysis, see, e.g., Rosen, 2015; Braveman and Gottlieb, 2014; Aue and Roosen, 2010). In private space, there is notable effort in provisioning, for example, wc toilet facility and connection to the public electricity grid. On the other hand, public infrastructure provisioning is marked by serious deficits, for example, electric power, potable water supply and waste collection.

Intrinsic in all the findings and analyses thereto is crass exclusion. For example, almost all households in our data universe are connected to the public electricity grid, yet this does guarantee electricity supply. Equally notable is total absence of public potable water. Even if USa is excluded from public potable water supply, there is ample evidence of concerted effort to breakout with private household water boreholes and ring-wells. In all instances of efforts at private provisioning, those with low income and low educational status fared worse than those with high incomes and high educational qualifications. The consistency of our data is maintained by the intersection between slum dwelling and insecurity where we also found that the less educated and low-income earners are more disadvantaged than other respondents. Sustained mass exposure to insecurity and pervasive negative perception of it have the potential of transforming USa into a feral district where government is functional but is not able to maintain rule of law.

Findings underscore the ontology of sustained exclusion of the urban poor and government's shrinking from public space. The most prominent exemplar is infrastructure deficit where the damning fallouts economic liberalism have been vividly demonstrated. Upholding the superiority of market forces since the mid-nineteen eighties, government has inexplicably withdrawn from the provision of urban utilities and services even as poverty and unemployment have mounted.

While public piped potable water is absent in the entire study area, there are two large public corporations (Urban Water Board and Rural Water Supply and Sanitation Agency), which exist only in name but are continually provided for in annual budgetary allocation of funds. To all intents and purposes, water supply is now a de facto private affair in USa and Edo State at large. Even more compelling is the example of electric power supply. Now fully commercialised and privatised, the most noticeable change has been the constant increase in electricity rates through the multi-year tariff order (MYTO). Ironically, government officials have now joined in the public criticism of the abysmal performance of the private electricity companies, thus busting the myth that private enterprise is the cure for any malaise. 
Intersectionality, Relativity and Multiple Deprivation in Upper Saponba Area, Benin City, Nigeria 118

In the USa slum, outsourcing of waste collection also falsifies the folklore of private enterprise, thus exposing the naivety of economic liberalism. Householders are left to the whims of waste collection companies whose performances are similar to that of the private electricity companies. Paying dues to government to retain their licenses, waste collections companies in turn collect dues from the public but do not seem to have much interest in rendering service as all parts of USa are littered with filth. The recurrent failure of private entrepreneurs to rescue privatised enterprise demands new thinking and innovative pro-poor social engineering in urban infrastructure and services provisioning.

Finally, on the question of security or lack of it, the state of affairs points to the ineffectiveness of government or total abdication of responsibility. Even though no official statement has been made, it appears householders and individuals have been left to provide their own security in USa. But defining security needs only in terms of crime security is untenable reductionism especially in view of the intersecting challenges of slumdwellers who are in need of infrastructural, health, job and housing security among others. Therefore, we are led to the predictable conclusion that poverty, social exclusion and the USa slum in Benin City are fallouts of an intersection of enervating social facts sustained by the agency of the neoliberal politico-economic structure.

\section{Intersectionality, multiple deprivation and public policy}

Public policy is usually directed at specific issues of interest with a specific purpose of proffering solutions to improve the wellbeing of people. As a political action, public policy is goal-directed, usually short-term and popular programme designed by the ruling group to fulfil electoral or other promises and enhance the popularity of regime and government. In short, public policy is reductionist, simple, incremental and usually with single targets and short-run goals or targets. However, focusing on single markers leads to a false classification of people that does not reflect lived realities. It ignores the fact that members of groups are affected by their positions in complex systems of power and inequalities which change over time and space (Palencia et al., 2014). Therefore, public policy is not able to effectively explain the nuances and complexities in the lives of real people by failing to address the intersections between axes of inequality (UNDESA, 2020; UN, 2017; Tsikata, 2016).

The goal of intersectionality in public policy is to identify and address the way specific policies resolvethe inequalities experienced by various social groups considering that social identities including race, class, gender, ability, geography, etc. interact to form unique meanings and complex experiences within and between groups in society (Stewart, 2014). As pointed out by Coll-Planas and SolaMorales (2019), intersectionality warns us of the biases and exclusions generated by public policies through aspects such as the definition of the people to whom policy is addressed and the mechanisms of participation. Therefore, intersectionality helps us recognize the diversity of situations and needs of the citizens. 
Application of intersectionality analysis in this study reminds us that neither the world nor our lives are one-dimensional. Slum is not merely a function of poverty as there are non-poor people living in the slum. Ecological inequality in the city is not merely a function of poverty or any other single factor. Intersectionality in social policy also emphasizes that poor people have other important life identities which affect or determine intra-group or intergroup relations. We are also alerted to the role of latent, larger and more powerful forces in the oppression, deprivation and exclusion of the poor. Without a recourse to intersectionality, public policy is ultimately futile.

\section{References}

Abdullahi, I.B., Sakariyahu, O.R. and Olatunji,A. (2016) "Unemployment menace and the fallacy of microcredit policy in Nigeria." African Journal of Economic Review4(2):171-187.https:// www.ajol.info/index.php/ajer/article/view/136055

Accessed 31/12/2020.

Acha, I. (2012) "Microfinance banking in Nigeria: problems and prospects." International Journal of Finance and Accounting 1(5): 106-111.DOI:10.5923/j.ijfa2012015.04 .

Accessed 31/12/2020.

Action on Smoking and Health (ASH, 2019) Smoking and poverty. London: ASH. https:// ash.org.uk/wp-content/uploads/2019/10/191016-Smoking-and-Poverty-2019-FINAL.pdf Accessed 26/12/2020.

Adama, O. (2007) Government from above. Solid waste management in Nigeria's new capital city of Abuja. Doctoral dissertation, Stockholm University.

https://www.diva-portal.org/smash/get/diva 2:197191/FULLTEXT01.pdf. Accessed 06/12/2020

Adejoh, S.O., Alabi, T.A., Adisa, W.B. and Emezie, N.M. (2019) “'Yahoo-boys' phenomenon in Lagos metropolis: a qualitative investigation." International Journal of Cyber Criminology 13(1):120.DOI:10.5281/zenodo.3366298

. Accessed 12/01/2021.

Adeniran, A.I. (2008) "The internet and emergence of Yahoo boys' subculture in Nigeria." International Journal of Cyber Criminology 2(2):368-381. www.cybercrimejournal.com/ adebusuyiijccdec2008.pdf

. Accessed 12/01/2021.

Albright, C.S., Winston, L.W. and Zappe, J.C. (2009) Data analysis and decision making with Microsoft Excel (Third edition). Mason, OH: South-Western College Publishing. 
Intersectionality, Relativity and Multiple Deprivation in Upper Saponba Area, Benin City, Nigeria 120

Alvarado, N. and Muggah, B. (2018) Crime and violence: obstacles to development in Latin American and Caribbean cities. Discussion Paper Number IDB-DP-644, Institute for Development Sector, Inter-American Development Bank (IDB). https://igarape.org.br/wp-content/ uploads/2018/11/Crimeand-Violence-ObstaclestoDevelopment.pdf

Accessed 05/12/2020.

Amudu, O. S., Adebisi, S. A., Jimodu, L. A. and Alade, A. O. (2014) "Challenges and possible panacea to the municipal solid waste management in Nigeria." Journal of Sustainable Development Studies 6(1):64-70.https://core.ac.uk/download/pdf/229606406.pdf. Accessed 06/12/2020

Amzat, J. and Razum, O. (2014). Medical Sociology in Africa. New York: Springer.

Angel, S., Sheppard, C., Civco, D.L., Buckley, R., Chabeava, A., Gitlin, L., Kvaley, A., Parent, J. and Perlin, M. (2005) The dynamics of global urban expansion. Washington DC: Transport and Urban Development Department, The World Bank. http://documents1.worldbank.org/curated/en/ 138671468161635731/pdf/355630Global0urban0sept200501PUBLIC1.pdf

Accessed 02/04/2020.

Arsht, A. (2012) Urbanisation in Latin America. Washington DC: Atlantic Council. 20140205_LatAm_UrbanizationTwoPage.pdf

Accessed 07/03/2020

Ashworth, W.J. (2017). The Industrial Revolution. The state, knowledge and global trade. London: Bloomsbury Publishing.

Aue, K. and Roosen, J. (2010) "Poverty and health behaviour: comparing socioeconomic status and a combined poverty indicator as a determinant of health behaviour." Selected paper prepared for presentation at the $1^{\text {st }}$ Joint EAAE/AAEA Seminar on The Economics of Food, Food Choice and Health, Freising, Germany, Sept 15-17. https://www.researchgate.net/publication/ 254386093_Poverty_and_health_behaviour_Comparing socioeconomic_status_and_a combined_poverty_ indicator_as_a_determinant_of_health_behaviour

. Accessed 06/12/2020.

Avis, W.R. (2019) Urban expansion in Nigeria. K4D Helpdesk Report 692. Brighton, UK: Institute of Development Studies. https://assets.publishing.service.gov.uk/media/ 5df7b30040f0b60959adc747/692_Urban_Expansion_of_Nigerian_Cities.pdf .Accessed 10/12/2020

Awabil, G and Anene, E. (2018) "The health behaviour inventory: initial development, factor structure and evidence of reliability.” Journal of Educational and Social Research 8(2):45-51.DOI:10.2478/ jesr-2018-0015

Accessed 25/12/2020. 
Awan, M.S., Malik, N., Sawar, M. and Waqas, M. (2011) "Impact of education on poverty." International Journal of Academic Research 3(1):569.664.

Avakian, T. (2018) "This African city could be the most populated in the world by the end of the century." Business Insider, April 8. businessinsider.com/this-african-city-could-be-themost.populated-in-the-world-by-2100-2018-4?IR-T

Accessed 13/03/2020.

Babatunde, M.A. and Oyejide, T.A. (2017) “Is growth immiserising in Nigeria?" Annals of the Social Science Academy of Nigeria 21:23-61.

Banerjee, A. and Duflo, E. (2011) Poor economics. A radical rethinking of the way to fight global poverty. New York: Pubic Affairs. https://warwick.ac.uk/study/summer-with-warwick/ warwick-summer-school/courses/macroeconomics/poor_economics.pdf

Accessed 03/01/2-21.

Beall, J. and Fox, S.B. (2012) "Mitigating conflict and violence in African cities." Environment and Planning C: Government and Policy 30(6):968-981.DOI:1068/c11333j

. Accessed 09/12/2020.

Bloch, R., Monroy, J., Fox, S. and Ojo, A. (2015) Urbanisation and urban expansion in Nigeria. Urban Research Nigeria (URN) Research Report. London: ICF International. https://core.ac.uk/ download/pdf/96701289.pdf

. Accessed 09/12/2020.

Bouston, L.P., Bunten, D. and Hearey, O. (2013) Urbanisation in the United States 1800-2000. National Bureau of Economic Research (NBER) Working Paper Series Number 19041. https:// scholar.princeton.edu/sites/default/files/lboustan/files/research21_urban_handbook.pdf . Accessed 06/12/2020.

Brady, D. (2019) “Theories of causes of poverty.” Annual Review of Sociology 45:155-173.https:/ /doi.org/10.1146/annurev-soc-073018-022550

Accessed 03/04/2020

Braveman, P. and Gottlieb, L. (2014) "The social determinants of health: it's time to consider the causes of the causes." Public Health Reports 129(Supp. 2):19-31. https://www.diva-portal.org/ smash/get/diva2:824535/FULLTEXT01.pdf.Accessed 06/12/2020.

Brenner, N. and Schmid, C. (2014) "The urban age in question." International Journal of Urban and regional Research33(3):731-755.DOI:10.1111/1488-2427.12115. Accessed 07/12/2020.

Broto, V.C. and Alves, S.N. (2018) "Intersectionality challenges for the co-production of urban services: notes for a theoretical and methodological agenda." Environment and Sustainability 30(2):367-386.DOI:10.1177/0956247818790208 Accessed 13/03/2020 
Intersectionality, Relativity and Multiple Deprivation in Upper Saponba Area, Benin City, Nigeria 122

Buck, R. and Deutsch, J. (2014) "Effects of education on poverty." Journal of Human Sciences 11(2):1139-1148.

www.j-humansciences.com/ojs/index.php/IJHS/article/view/3043 Accessed 27/03/2020.

Cameron, R. (1983). "A new view of European industrialisation." The Economic History Review (New Series) 30(1):1-23.

http://smjegupr.net/wp-content/uploads/2012/05/industrialization-in-europe.pdf

. Accessed 08/12/2020.

Castells-Quintana, D. and Wenban-Smith, H. (2020) "Population dynamics, urbanisation without growth, and the rise of megacities." Journal of Development Studies 56(9):1663-1682.https:// www.tandfonline.com/doi/epub/10.1080/00220388.2019.1702160?needAccess=true Accessed 10/12/2020

Cochran, W.G. (1977) Sampling techniques. Third edition. New York: John Wiley and Sons.

Cohen, B. (2006). "Urbanisation in developing countries: current trends, future projections and key challenges for sustainability." Technology in Society 28(1):63-80.DOI:10.1016/ j.techsoc.2005.10.005

Accessed 07/04/2020.

Colenbrander, S. (2016) Cities as engines for economic growth: the case for providing infrastructure and services in urban areas. Human Settlement Group, International Institute for Environment and Development Working Paper. https://pubs.iied.org/pdfs/10801IIED.pdf. Accessed $10 / 12 / 2020$.

Coll-Planas, G. and Sola-Morales, R. (2019) Toolkit to incorporate intersectionality into local policies. http://igualtatsconnect.cat/wp-content/uploads/2019/06/Publicacion-Igualtats-ConnectENG-2.pdf . .Accessed 28/03/2020

Cuthbertson, P. (2018) Poverty and crime: why a new war on criminals would help the poor most. London: Cavitas. https://www.civitas.org.uk/content/files/povertyandcrime.pdfAccessed 12/ $01 / 2021$

Cwynar, A., Cwynar, W., Parda, R. and Wals, K. (2016) "Loan perception and loan-related attitude of Poles: evidence from the field." Forum Scientiae Oe economica 4(2):37-58.https:// www.researchgate.net/publication/308478263 LOAN_PERCEPTION_AND_LOANRELATED ATTITUDE OF POLES EVIDENCE FROM THE FIELD

Accessed 25/12/2020

Davis, E.P. and Sanchez-Martinez, M. (2014) A review of the economic theories of poverty. Discussion Paper No. 435, National Institute of Economic and Social Research, London. niesr.ac.uk/ sites/default/files/publications/dp435_0pdf Accessed 03/04/2020. 
Dobbs, R., Smit, S., Remes, J., Manyika, J., Roxburgh, C. and Restrepo, A. (2011) Urban world: mapping the economic power of cities. The McKinsey Global Institute. https:// www.mckinsey.com/ /media/mckinsey/featured\%20insights/urbanization/urban\%20world/ mgi_urban_world_mapping_economic_power_of_cities_full_report.ashx.Accessed 09/12/2020

Dodman, D., Leck, H., Rusca, S. and Colenbrander, S. (2017) “African urbanisation and urbanism: implications for risk accumulation and reduction." International Journal of Disaster Risk Reduction 26:7-15.https://www.sciencedirect.com/science/article/pii/S2212420917300237.Accessed 09/12/ $\underline{2020}$

Duvendack, M., Palmer-Jones, R., Copestake, J.G., Hooper, L., Loke, Y. and Rao, N. (2011) What is the evidence of the impact of microfinance on the wellbeing of the poor? London: EPPI-Centre, Social Science Research Unit, Institute of Education, University of London. https://www.givedirectly.org/wp- content/uploads/2019/06/DFID microfinance evidence review. pdf Accessed 25/12/2020.

Earnshaw, V.A., Rosenthal, L., Gilstad-Hayden, K. Carrol-Scott, A., Kershaw, T.S., Santilli, A. and Ickovics J.R. (2018) “Intersectional experiences of discrimination in a low resource urban community: an exploratory latent class analysis. Journal of Community and Applied Psychology 35(1):94-101. https://doi.org/10.1002/casp.2342

Accessed 04/12/2020.

Economic and Social Research Council (ESRC, 2014) Poorer people are less physically active. https://esrc.ukri.org/files/news-events-and-publications/evidence-briefings/poorer-people-are-lessphysically-active/Accessed 26/12/2020

Elmquist, T., Anderson, E., Frantzeskaki, N., McPhearson, T., Olsson, P., Gaftney, O., Takeuchi, K. and Folke, C. (2019) "Sustainability and resilience for transformation un the urban century." Nature Sustainability 2:267-273.https://www.stockholmresilience.org/publications/artiklar/201904-10-sustainability-and-resilience-for-transformation-in-the-urban-century.html Accessed 07/12/2020.

Emerson, P.M. (2010) Are microloans bad for growth? IZA Discussion Paper Number 5249. http://ftp.iza.org/dp5249.pdf

Accessed 25/12/2020.

Ewetan, O.O. and Urhie, E. (2014) "Insecurity and socio-economic development in Nigeria." Journal of Sustainable Development Studies5(1):40-65.

Fafchamps, M. (2015) Credit constraints, collaterals and lending to the poor. Paper prepared for Revue d'Economic Developpement. https://web.stanford.edu/ fafchamp/endgame.pdf

Accessed 25/12/2020. 
Intersectionality, Relativity and Multiple Deprivation in Upper Saponba Area, Benin City, Nigeria 124

Farrell, K. (2017) "The rapid urban growth triad: a new conceptual framework for examining the urban transition in developing countries." Sustainability 9(1407):1-19. www.doi.10.3390/ su9081407.

Accessed 07/12/2020.

Farrell, K. (2018) Rapid urbanisation: an inquiry into the nature and causes of the urban transition in developing countries. Doctoral thesis in Urban and regional Studies, Stockholm, Sweden.

http://www.diva-portal.org/smash/get/diva2:1257531/FULLTEXT01.pdf. Accessed 05/04/2020.

Feinstein, L., Sabates, R., Anderson, T.M., Somaindo, A. and Hammond, C. (2006) "What are the effects of education on health?" Proceedings of the Copenhagen Symposium on The Effects of Education on Health and Civic Engagement. www.oecd.org/education/innovation-education/ 37425753.pdf

Accessed 27/12/2020.

Ferreira, F.H.G., Chen, S., Dabalen, A., Dikhanov, Y., Hamadeh, N., Joliffe, D., Narayan, A., Prydz, E.B., Ravenga, A., Sangraula, P., Serajuddin, Y., and Yoshida, N. (2015) A global count of the extreme poor in 2012. Data issues, methodology and initial results. World Bank Policy Research Working Paper 7432. http://pubdocs.worldbank.org/en/131721487259082687/ SessionII-A-global-count-of-the-extreme-poor-in-2012.pdf Accessed 02/01/2021.

Florczyk, A.J., Melchiorri, M., Zeidler, J., Corbane, C., Schiavina, M., Freire, S., Sabo, F., Politis, P., Esch, T. and Pesaresi, M, (2020) "The generalized settlement area: mapping the earth surface in the vicinity of built-up areas." International Journal of Digital Earth 13(1):45-60.https:// www.tandfonline.com/doi/full/10.1080/17538947.2018.1550121. Accessed 04/12/2020.

Flyvbjerg, B. (2006) "Five misconceptions about case study research." Qualitative Inquiry 12(2):219-245. DOI:101177/1077800405284363 .Accessed 10/12/2020.

Fox, S. (2011) Understanding the origins and pace of Africa's urban transition. LSE: Crisis States Research Centre, Working Paper Number 89. https://www.lse.ac.uk/internationaldevelopment/Assets/Documents/PDFs/csrc-working-papers-phase-two/wp89.2-origins-and-paceof-africas-urban-transition.pdf Accessed 09/12/2020

Greenhalph, E.M., Bayly, M. and Scollo, M. (2020) "Trends in prevalence of smoking by socioeconomic status.” In Greenhalph, E.M., Scollo, M.M. and Winstanley, M.H. (eds). Tobacco in Australia. Facts and issues. Melbourne: Cancer Council Victoria.

https://www.tobaccoinaustralia.org.au/chapter-1-prevalence/1-7-trends-in-the- prevalence-ofsmoking-by-socioec

Accessed 26/12/2020 
Hancock, A.M. (2007) "When multiculturalism does not equal quick addiction. Examining intersectionality as a research paradigm." Perspectives on Politics 5(1):63-79. DOI:10.1017/ S1537592707070065 Accessed 28/03/2020.

Harkness, S., Gregg, P. and MacMillan, L. (2013) Poverty: the role of institutions, behaviours and culture. JRF Programme Paper. www.jrf.org.uk/sites/default/files/jrf/migrated/files/povertyculture-behaviour-full.pdf Accessed 25/12/2020.

Harley, C.K. (2013) British and European industrialisation. University of Oxford Discussion Papers in Economic and Social History Number 111. https://www.nuff.ox.ac.uk/economics/history/ Paper111/harley111.pdf Accessed 08/12/2020

He, C., Liu, Z., Gou, S., Zhang, Q., Zhang, J. and Xu, L. (2019) “Detecting global urban expansion over the last three decades using a fully convolutional network." Environmental Research Letters 14:1-17.https://iopscience.iop.org/article/10.1088/1748-9326/aaf936/pdf . Accessed 04/04/2020.

Hofmann, A. and Wan, G. (2013) Determinants of urbanisation. Asian Development Bank (ADB) Economics Working Paper Number 355. https://www.adb.org/sites/default/files/publication/30316/ ewp-355.pdf .Accessed 08/12/2020

Hoornweg, D. and Pope, K. (2016) "Population prediction for the world's largest cities in the $21^{\text {st }}$ century." Environment and Urbanization 29(1):195-210.DOI:10.1177/0958247816663557 Accessed 13/03/2020

Horn, J., Rosenland, L.N. and Smith, M.R. (eds) (2010) Reconceptualising the Industrial Revolution. Cambridge, Mass: The M.I.T Press.

Hosseinpoor, A.R., Parker, L.A., d'Espaignet, E.T. and Chatterji, S. (2012) "Socioeconomic inequality in smoking in low- and middle-income countries: results from the World Health Survey." PLos ONE 7(8):e42843. DOI:10.1371/journal.pone.0042843 Accessed 26/12/2020.

Hove, M., Ngwerume, E.T. and Muchemwa, C. (2013) "The urban crisis in sub-Saharan Africa: a threat to human security and sustainable development." Stability: An International Journal of Security and Development 2(1):1-14.https:/www.stabilityjournal.org/articles/10.5334/sta.ap/. Accessed 09/12/2020.

Igun, U. (2015) “Mixed method research: a new paradigm?” Annals of the Social Science Academy of Nigeria20:126-131.

Ioris, A. (2015) "Latin America's large-scale urban challenges: development failures and public service inequalities in Lima, Peru." ACME: An International e-Journal for Critical Geographies14(4):1161-1186.http://orca.cf.ac.uk/99033/1/A\% 20 Ioris \%202015\%20Latin\% 20America's\%20Large Scale\%20Urban\%20Challenges\%20OApub\%20ver.pdf 
Intersectionality, Relativity and Multiple Deprivation in Upper Saponba Area, Benin City, Nigeria $\quad 126$

. Accessed 08/12/2020.

Jedwab, R., Gollin, D. and Vollrath, D. (2013) Urbanisation with and without industrialisation.Institute of International Economic Policy Working Paper Series (IIEP-WP-20141), The George Washington University. https://www2.gwu.edu/ iiep/assets/docs/papers/ Jedwab_IIEPWP_2014-1.pdf. Accessed 09/12/2020

Jones, L. and Sumnall, H. (2016) Understanding the relationship between poverty and alcohol misuse. Liverpool John Moores University: Centre for Public Health (CPH). https:// www.drugsandalcohol.ie/25676/1/Understanding-the-relationship-between-poverty-and-alcoholabuse-2.pdf. Accessed 03/01/2021

Justus, M., Sant'Anna, E.G., Davanzo, E.S. and Moreira, G.L. (2020) “Education and smoking behaviour in Brazil: decision to smoke and daily consumption intensity." Nova Economica30(2):679700. https://doi.org/10.1590/0103-6351/4950

Accessed 27/12/2020.

Karriker-Jaffe, K.J., Roberts, S.C.M. and Bond, J. (2013) "Income inequality, alcohol use and alcohol related problems." American Journal of Public Health 103(4):649-656.www.doi:10.2015/ AJPH.2012.300882

Accessed 03/01/2021.

Khan, A. (2008) "Tackling the failure of microfinance efforts through amalgamating microfinance with charity: two viable alternatives in the context of Pakistan." Australasian Accounting, Business and Finance Journal 2(2):19-33.doi:10.14453/11bfj.v2i2.2

Accessed 20/12/2020.

Khan, H. (2008) Challenges for sustainable development: rapid urbanisation, poverty and capabilities in Bangladesh. Munich Personal RePEc Archive (MPRA) Paper No. 9290. https:// mpra.ub.uni-muechen.de/9290/

Accessed 13/03/2020

Khawari, A. (2004) Microfinance: does it hold its promise? A survey of recent literature. HWWADiscussion Paper 276, Hamburg Institute of International Economics.

https://www.econstor.eu/obitstream/10419/19248/1/276.pdf. Accessed 25/12/2020

Kim, I. and So, W. (2014) "The relationship between household income and physical activity." Journal of Physical Therapy Science26(12):1887-1889. www.doi:1058/jpts.26.1887

. Accessed 26/12/2020.

Kimani-Murage, E.W. and Ngindu, A. (2007) "Quality of water the slum dwellers use: the case of a Kenyan slum." Journal of Urban Health: Bulletin of the New York Academy of Medicine 
127 Annals of the Social Academy, Nos. 22, Jan.-Dec., 2018/2019

84(6):829-839.doi.10.1007/s11524-007-9199x～. Accessed 03/01/2021.

Kourtit, K., Nijkamp, P. and Stough, R.R. (eds.) (2015). The rise of the city: spatial dynamics in the urban century. Cheltenham, UK: Edward Elgar.

Kourtit, K. and Nijkamp, P. (2015) "Cities of the future: research challenges in the urban century." Romanian Journal of Regional Science 4(1):1-16.http://www.rrsa.ro/rjirs/V911.KOURTIT.PDF . Accessed 07/12.2020

Lapenu, C. (2000). The role of the state in promoting microfinance institutions. FCND Discussion Paper No, 89, International Food Policy Research Institute.

Larson, E., George,A., Morgan, R. and Poteat, T. (2016) “10 best resources on... intersectionality with an emphasis on low- and middle-income countries." Health Policy and Planning 8:16.DOI:10.1093/heapol/czw020 Accessed 27/03/2020.

Li, X., Zhou, Y., Eom, J., Yu, S. and Asrar, G.R. (2019) "Projecting global urban area growth through 2100 based on historic and time series data and future shared socioeconomic pathways." Earth's Future 7:1-12.DOI:10.1029/2019F001152 .Accessed 09/12/2020.

Loring, B. (2014) Tobacco and inequities. Guidance for addressing inequities in tobaccorelated harm. Copenhagen: WHO Office for Europe.

https://www.euro.who.int/ data/assets/pdf_file/0005/247640/tobacco-090514.pdf?ua=1

Accessed 26/12/2020.

Mabogunje,A.L. (2005) “Global urban poverty research agenda: the African case.” Paper presented at the seminar on Global urban poverty: setting the research agenda. Washington DC, December 15. https://www.citiesalliance.org/sites/default/files/mabogunjepaper\%5B1\%5D.pdf

. Accessed 09/12/2020.

Marr, A. (2004) "A challenge to the orthodoxy concerning microfinance and poverty reduction." Journal of Microfinance 5(2):1-35.

Mathis, F. (2013) "No industrialisation without urbanisation: the role of cities in western economic development." In Exenberger, A., Strobl, P. and Bischol, G. (eds), Globalisation and the city. Two connected phenomena in the past. Innsbruck: Innsbruck University Press, pp. 23-38. https:/ /books.openedition.org/iup/1357?lang=en . Accessed 08/12/2020.

Matthew, T.R. (2000) Invisible women: understanding the barriers to physical activity for low-income older adult women. MSc thesis, University of Alberta. www.collectionscanada.ga.ca/ obj/s4/f2/ftp01/MQ59844.pdf Accessed 24/12/2020.

Mecha, N.S. (2017) "Effect of microfinance on poverty reduction: a critical scrutiny of theoretical literature." Global Journal of Commerce and Management Perspectives 6(3):16-23. https:// www.longdom.org/articles/effect-of-microfinance-on-poverty-reduction-a-critical-scrutiny-oftheoretical-literature.pdf Accessed 25/12/2020. 
Intersectionality, Relativity and Multiple Deprivation in Upper Saponba Area, Benin City, Nigeria 128

Meerkotter,A. (2019) "Unjust cities and the institutional failure of punitive solutions to poverty." In Howell, S. Policing the urban periphery in Africa. Developing safety for the marginal. Cape Town: African Policing Civilian Oversight Forum (APCOF). http://apcof.org/wp-content/uploads/ apcofpolicingtheurbaneng.pdf Accessed 12/01/2021.

Megaloni, B., Franco, E. and Melo, V. (2015) Killing in the slums: an impact evaluation of police reform in Rio de Janeiro. Stanford: Centre for International Development. https:// siepr.stanford.edu/sites/default/files/publications/556wp_9.pdf Accessed 12/01/2021

Mihal, M., Titan, E. and Todose, D.M. (2015) "Education and poverty." Procedia Economics and Finance 15:855-860.DOI:10.101652212-5671(15)01532-4 Accessed 27/03/2020.

Mohajan, H.K. (2019) "The first Industrial Revolution: creation of a new global human era." Journal of Social Sciences and Humanities 4(4):377-387.https://mpra.ub.uni-muenchen.de/96644/1/ MPRA_paper_96644.pdf

. Accessed 08/12/2020

Moser, C., Winston, A. and Moser, A. (2005) "Violence, fear and insecurity among the poor in Latin America." In Fay, M. (ed). The urban poor in Latin America. Washington DC: The World Bank.

Muggah, R. (2013) Researching the urban dilemma: urbanization, poverty and violence. Ottawa: International Development Research Centre.

Muhammed, S.N., Saibu, N. and Khalil, M.S. (2015) “An overview of urbanisation and its challenges on sustainable development in Nigeria." Dutse Journal of Pure and Applied Sciences 1(1):19$29 . \mathrm{ht} \mathrm{t} \mathrm{p} \mathrm{s}: / / \mathrm{w} \mathrm{w}$ w. re s e a r c h g a t e. ne t/p u b 1 i c a t i o n / 318876748_AN_OVERVIEW_OF_URBANIZATION_AND_ITS_CHALLENGES_ON_ SUSTAINABLE_DEVELOPMENT_IN_NIGERIA.Accessed 10/10/2020

Murad, A.B. and Idewele, I.E.O. (2017) "The impact of microfinance institutions in economic growth: Nigeria in focus." International Journal of Development and Management Review 12(1):1-17.

Nelly, V., de Snyder, S, Friel, S., Fotso, J.C., Khadr, Z., Meresman, S., Monge, P. and PatilDeshmulch,A. (2011) "Social conditions and urban inequalities: realities, challenges and opportunities to transform urban landscape through research and action." Journal of Urban Health 86(6):11831193. doi:10.1007/s11524-001-9609-y

Accessed 02/04/2020

Noll, S.E. (2019) "Health justice in the city: why intersectional analysis of transportation matters." Essays in Philosophy 20(2):1-16.DOI:10.7710/1526-0569.1632

Accessed 10/03/2020. 
Okeke, D. (2017) "Reflections on urbanisation without industrialisation - espousing the space economy hypothesis." Paper at the Conference on Industrialisation, Urbanisation and ChinaAfrica Cooperation, Addis Ababa. https://www.researchgate.net/publication/ 319165849_Reflections_on_urbanization_without_industrialization_in_Africa__espousing_the_space_economy_hypothesis .Accessed 08/12/2020.

Okolocha, C.F. (2014) The afropolis in the African urban revolution. Benin City: University of Benin Press.

Oloworekende, A. (2019) No more insufficient funds. Yahoo yahoo and cybercrime's international ecosystem. Available at: https://republic.com.ng/august-september-2019/yahooyahoo-naija/ .Accessed 12/01/2021.

Onapajo, H. and Uzodike, U.O. (2017) Poverty and social violence in Africa: Nigeria as case study. AfriHeritage Research Working Paper 2017-005. https://media.africaportal.org/documents/ Poverty-and-Social-Violence-in-Africa-Nigeria-as-Case-STudy-2.pdf

. Accessed 09/12/2020.

Onime, B.E. (2018) "Insecurity and economic growth in Nigeria: a diagnostic review." European Scientific Journal 14(4):377-391. http://dx.doi.org/10.19044/esj.2018,v14n4p.377

Accessed 29/03/2020.

Organisation for Economic Cooperation and Development (OECD) (2015) The metropolitan century. Paris: OECD. https://doi.org/10.1787/9789264228733-en Accessed 07/12/2020.

Otolorin, G.E. (2017) “Determinants of human insecurity in Nigeria and their impact on economic growth.” Paper presented at the South-South Economic Conference, Nigeria Economic Society,

Port Harcourt, 6-8 November. https://papers.ssrn.com/so13/Data_Integrity_Notice.cfm?abid = 3150429 . Accessed 29/03/2020.

Palencia, L., Malmusi, D. and Borrell, C. (2014) "Incorporating intersectionality in evaluation of policy impacts on health equity. A quick guide.” Sophie.

www.sophie-project.eu/pdf/Guide_intersectionality_SOPHIE.pdf. Accessed 05/04/2020.

Palmer, R., Wedgwood, R., Hayman, R., King, K. and Thin, N. (2007) Educating out of poverty? A synthesis report on Ghana, India, Kenya, Rwanda, Tanzania and South Africa. DFID Educational Papers, Centre of African Studies, University of Edinburgh.

Parvez, A., Rahman, M.M., Sultana, S. and Shaheen, S.M. (2019) "Prevalence of water-borne disease in Farmgate slum of Dhaka City: a case study of disease propagation in Bangladesh." Pharmacologyonline 1(Archives):55-63.5e5ece384585152ce808e178.pdf . Accessed 03/01/2021. 
Intersectionality, Relativity and Multiple Deprivation in Upper Saponba Area, Benin City, Nigeria 130

Patel, R.B and Burkle Jr, F.M. (2012) "Rapid urbanisation and the growing threat of violence and conflict: the $21^{\text {st }}$ century crisis. Prehospital and Disaster Medicine 27(2):194-197.https://doi.org/

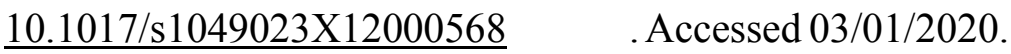

Pervez, S. (2014) "Impact of education on poverty: a co-integration analysis for Pakistan." Journal of Research in Economics and Finance (JREIF) 3(4):83-89.DOI:http:/dx.doi.org/10.1403/jreif2014.039 . Accessed 27/03/2020.

Pomeranz, D. (2014) The promise of microfinance and women's empowerment. What does the evidence say? EY Publications. https://www.hbs.edu/faculty/Publication\%20Files/EYThe\%20promise-of-microfinance-and-womens-empowerment_14123436-7f3a-4a87-a76f94e931c9ed5e.pdf Accessed 30/12/2020.

Portes, A. and Martinez, B.P. (2019) Latin American cities: their evolution under neoliberalism and beyond. $\mathrm{https} / / / \mathrm{cmd}$.princeton.edu/sites/cmd/files/media/latin_american_cities.pdf . Accessed 04/12/2020.

Rabb, T.K. and Rotberg, R.I. (2014) Industrialisation and urbanisation. Princeton: Princeton University Press. https://muse.jhu.edu/book/33873 . Accessed 06/12/2020.

Raleigh, C. (2015) “Urban violence patterns across African cities.” International Studies Review 17(1):90-106. https://doi.rog/10.1111/mistr.12206. Accessed 09/12/2020.

Reiman, J. and Leighton, P. (2016) The rich get richer and the poor get prison. Ideology, class and criminal justice. $10^{\text {th }}$ edition. New York: Routledge.

Ritchie, H. and Roser, M. (2019) “Urbanisation.” Our World in Data. https://ourworldindata.org/ urbanization . Accessed 09/12/2020.

Roberts, J.D., Mandic, S., Fryer, C.S., Brachman, M.L. and Ray, R. (2019) "Between privilege and oppression: intersectional analysis of active transportation experiences among Washington D.C area youth." International Journal of Environmental Research and Public Health 16(8):118.doi:103390/ijerph16081313 Accessed 02/03/2020.

Rodgers, D., Beall, J. and Kanbur, R. (2011) Latin American urban development into the $21^{\text {st }}$ century. Towards a renewed perspective on the city. World Institute for Development Economics Research, United Nations University (UNU-WIDER) Working Paper Number 2011/05. https:// www.wider.unu.edu/sites/default/files/wp2011-005.pdf ．Accessed 04/12/2020

Rogalsky, J. (2009) “"Myth busters': dispelling the culture of poverty myth in the urban classroom.” Journal of Geography 108(4-5):198-209. DOI:1080/00221340903344953

Accessed 25/12/2020. 
Romero,A.J. (2005). "Low-income neighbourhood barriers and resources for adolescents' physical activity." Journal of Adolescent Health 36(3):253-9.DOI:10.1016/j.jadohealth.2004.02.027 Accessed 26/12/2020.

Rose, P. and Dyer, C. (2008) Chronic poverty and education: a review of literature. Working Paper No. 131. Manchester: Chronic Poverty Research Centre.

Rosen, I. (2015) The impact of culture on health. A study of risk perception on unhealthy lifestyles in Babati town, Tanzania. Thesis submitted to the School of Natural Science, Technology and Environmental Studies, Soderton University.

https://www.diva-portal.org/smash/get/diva2:824535/FULLTEXT01.pdf

. Accessed 06/12/2020

Samman, E. (ed.) (2014) Group inequality and intersectionality. E-Bulletin of the Human Development and Capability Association No. 14 (July) https:/www.odi.org/sites/odi.org.uk/files/ odi-assets/publications-opinion-files/9173.pdf Accessed 13/03/2020

Sandven, B.R. and Thormodsen, S.S. (2012) The impact of the classical microfinance contract on the poor entrepreneur: a field experiment on entrepreneurs in Tanzania. MSc. Thesis, Norges Handelshoyskole. https://core.ac.uk/download/pdf/52072125.pdf

Accessed 25/12/2020.

Satterthwaite, D. (2011) “Editorial: Why is urban health so poor even in many successful cities?" Environment and Health 23(1):5-11.DOI:10.1177/0956247811401521

Accessed 03/04/2020.

Satterthwaite, D. (2007) The transition to a predominantly urban world and its underpinnings. International Institute for Environment and Development (IIED) Human Settlements Discussion Paper Series. Theme: Urban Change 1. https://pubs.iied.org/pdfs/10550IIED.pdf . Accessed 04/12/2020.

Scheim, A.I. and Bauer, G.R. (2019) "The intersectional discrimination index: development and validation of measures of self-reported enacted and anticipated discrimination for inter-categorical analysis." Social Science and Medicine 226:225-235. https://doi.org/10.1016/ j.socscimed.2018.12.016 Accessed 13/03/2020

Scroggins, M. (2015) Culture of poverty: critique. International Encyclopaedia if the Social and Behaviuoral Sciences (Second Edition), pp. 590-595.

https://www.academia.edu/37815723/Culture of Poverty_Critique Accessed 25/12/2020.

Smith, H.J., Pettigrew, T.F., Pippin, G.M. and Bialosiewicz, S. (2015) "A meta-analytic critique of relative deprivation.” Social Justice research 28(1):1-81. www.DOI:10.1007/s11211-014-02315. .Accessed 10/01/2021. 
Intersectionality, Relativity and Multiple Deprivation in Upper Saponba Area, Benin City, Nigeria 132

Smith, H.J. and Huo, Y.J. (2014) "How subjective experiences of inequality influence social behaviour and health." Behavioural and Brain Sciences 1(1):231-238.DOI:10.1177/2372732214550165 . Accessed 10/01/2021.

Sreermareddy, C.T., Pradhan, P.M. and Sin, S. (2014) "Prevalence, distribution and social determinants of tobacco use in 30 sub-Saharan African countries." BMC Medicine 12(243):1-13. https://doi.org/10.1186/s12916-014-0243-x

Accessed 27/12/2020

Steinsson, J. (2020) How did growth begin? The Industrial Revolution and its antecedents. https:/eml.berkeley.edu/ jsteinsson/teaching/originsofgrowth.pdf .Accessed 08/12/2020.

Stewart, F. (2017) Horizontal inequalities. Barriers to pluralism. Accounting for Change in Diverse Societies, Global Centre for Pluralism, Oxford. https://www.pluralism.ca/wp-content/ uploads/2017/10/Frances_Stewart_-_Horizontal_Inequalities_ENG.pdf.

Accessed 05/04/2020.

Stewart, F. (2015) Horizontal inequality. Professional Development Reading Pack No. 8. http:// gsdrc.org/docs/open/reading-packs/horizontalinequalitiesrp.pdf Accessed 05/04/2020.

Stewart, F. (2014) "Horizontal inequalities and intersectionality.” In E. Samman (ed.) Group inequality and intersectionality. E-Bulletin of Human Development and Capability Association No.24. https://www.odi.org/sites/odi.org.uk/files/odi-assets/publications-opinion-files/9173.pdf . Accessed 05/02/2020.

Sverdlik, A. (2011) "Ill-health and poverty: a literature review on health in informal settlements." Environment and Health 23(1):123-155.DOI:10.1177/0956247811398604

Accessed 03/04/2020.

Swain, R.B. (2004) Is microfinance a good poverty alleviation strategy? Evidence from impact assessment. SIDA Making Markets Work for the Poor Series. https://www.researchgate.net/ publication/267632970_Is_Microfinance_a_Good_Poverty_Alleviation_Strategy Accessed 30/12/2020/

Tacoli, C., McGranahan, G. and Satterthwaite, D. (2014) Migration, rural-urban migration and urban poverty. World Migration Report 2015: Migration and cities: new paradigm to manage mobility. Geneva: International Organization for Migration.

Teegavarapu, S and Summers, J.D. (2008) “Case study method for design research: a justification." Proceeding of the IDETC/DTM International Design Engineering Technical Conference, 2-6August, New York. DOI:10.1115/DETC2008-49980

. Accessed 10/12/2020. 
Tsikata, D. (2016) "Understanding and addressing inequalities in the context of structural transformation in Africa: a synthesis of seven country studies." Development 58:206-229.https:// doi.org/10.1057/s41301-016-0002-8

Accessed 05/04/2020.

Turok, I. and McGranahan, G. (2019) "Urbanisation and economic growth: the arguments and evidence for Africa and Asia." Urbanisation 4(2):109-125. www.doi.org/10.1177/ 2455737119890450

. Accessed 09/12/2020.

Uchendu, O. H. (2016) Household waste disposal laws in the Federal Republic of Nigeria. Capstone submitted to the Graduate School of Georgia State University in partial fulfilment of the requirements for the degree of Master of Public Health. https://scholarworks.gsu.edu/cgi/ viewcontent.cgi?article=1040\&context=iph_capstone Accessed 06/12/2020.

United Nations, Department of Economic and Social Affairs (UNDESA). (2020) World Social Report 2020. Inequality in a rapidly changing world. New York: United Nations. https:// www.un.org/development/desa/dspd/wp-content/uploads/sites/22/2020/01/World-Social-Report2020-FullReport.pdf Accessed 05/04/2020.

United Nations (UN) (2017) "The social inequality matrix: age as an axis of social inequalities." Social Panorama of Latin America 2016. New York: United Nations. https://doi.org/10.18356/ 8635ebf1-en Accessed 05/04/2020.

United Nations Development Programme (UNDP) (2018) What does it mean to leave no one behind? AUNDP discussion paper and framework for implementation. http://www.undp.org/content/ $\mathrm{dam} / \mathrm{undp} / \mathrm{i}$ ibrary/Sustainable \% $20 \mathrm{Deve} 1$ opment $/ 2030 \% 20 \mathrm{Agenda/}$ Discussion_Paper_LNOB_EN_lres.pdf Accessed 4/4/2020.

UN-Habitat. (2011) The economic role of cities/Nairobi: UN-Habitat. http://urban-intergroup.eu/ wp-content/files_mf/economicroleofcities_unhabitat11.pdf . .Accessed 09/12/2020.

Vidal, J. (2018) Overstretched cities. The 100 million city: is $21^{\text {st }}$ century urbanisation out of control? The Guardian, 19 March. https://www.theguardian.com/cities/2018/mar/19/urban-explosionkinshasa-el-alto-growth-mexico-city-bangalore-lagos . Accessed 09/12/2020.

Varenne, H. and Scroggins, M. (2015) "Culture of poverty: critique." International Encyclopaedia of the Social and Behavioural Sciences Vol.5 (Second edition). https://doi.org/10.1016/B9780-08=097086-8.64091.6 Accessed 03/04/2020. 